\title{
Pharmacotherapy in chronic kidney disease hyperphosphatemia - effects on vascular calcification and bone health
}

\author{
Dimce Dzingarski, Kristina Mladenovska* \\ Faculty of Pharmacy, University "Ss Cyril and Methodius", Mother Theresa St. 47, \\ 1000 Skopje, Republic of Macedonia
}

Received: October 2017; Accepted: December 2017

\begin{abstract}
Hyperphosphatemia (HP) in patients with chronic kidney disease (CKD) leads to complications such as renal osteodistrophy, cardiovascular calcification and hemodynamic abnormalities, all of them having a serious impact on the survival rate and quality of life. Also, HP is a key pathogenic factor in the development of secondary hyperparathyroidism (SHPT) in CKD. Having in regard the significance of controlling serum phosphorus levels $(\mathrm{Pi})$, in this paper, the needs and obstacles to successful pharmacological management of HP in CKD are presented, with an overview of major classes of phosphate binders (PBs) and other drugs affecting Pi level, such as active vitamin D sterols and calcimimetics (CMs). In addition, their effects on progression of cardiovascular calcification and bone health are elaborated. In this regard, a PubMed search was carried out to capture all abstracts and articles relevant to the topic of CKD, HP and mineral metabolism, bone disorders and vascular/valvular calcification (VC), published from January 2007 to August 2017. The search was limited to English language, with the search terms including drug name AND hyperphosphatemia or cardiovascular calcification or bone disorder. Comparative studies, clinical studies/trials and meta-analyses related to different classes/representatives of $\mathrm{PBs}$, vitamin D analogues and CMs were reviewed and research data related to their efficacy and safety compared.
\end{abstract}

Keywords: chronic kidney disease, hyperphosphatemia, phosphate binders, active vitamin D sterols, calcimimetics, bone disorders, cardiovascular calcification

\section{Introduction}

Chronic kidney disease (CKD) is a world-wide public health problem, with adverse outcomes of kidney failure, cardiovascular disease and premature death. Recently performed meta-analysis has shown that the mean global prevalence of CKD was $13.4 \%$ for the populations $(n=44)$ that measured prevalence by all 5 stages ( 1 to 5 ), and $10.6 \%$ in the populations ( $\mathrm{n}=68)$ measuring stages 3 to 5 . CDK prevalence by geographical grouping has shown mean prevalence of $18.38 \%(\mathrm{n}=821.902)$ and $11.86 \%$ $(\mathrm{n}=2.169 .183)$ in European population, measuring stages 1 to 5 and 3 to 5 , respectively (Hill et al., 2016). The prevalence of CKD stages in the Macedonian population (adjusted by age and gender to the general population, with the population census in 2002) was determined as well, being highest for the stage $3(7.1 \%)$ and lowest for the stage $5(0.18 \%) \quad(n=2.637$; mean age $45.97 \pm 16.55$; male 44.14\%) (Stojceva-Taneva et al., 2016).

Progression of CKD is associated with serious complications. Nutritional requirements are altered and metabolisms of protein, water, salt, potassium and

\footnotetext{
*krml@ ff.ukim.edu.mk
} 
phosphorous are affected, which leads to ineffective energy generation despite adequate intake of protein and carbohydrate substrates. In more extreme manifestations, these alterations cause "uremic malnutrition" associated with anorexia, nausea, vomiting, volume overload, hyperkalemia, metabolic acidosis and hyperphosphatemia (HP), and abnormalities related to hormonal or systemic dysfunction (e.g. hypertension, anemia, hyperlipidemia, pericarditis, peripheral neuropathy, CNS abnormalities and bone disease).

\section{Hyperphosphatemia in CKD patients}

HP indicates plasma phosphorus $(\mathrm{Pi})$ concentration $>$ $5 \mathrm{mg} / \mathrm{dL}$ in the adults and $7 \mathrm{mg} / \mathrm{dL}$ in the adolescents. Patients on hemodialysis (HD) with a Pi level above the NKF-K/DOQI Guideline target levels have a $40 \%$ higher mortality rate when compared to those having target levels.

The kidney plays a major role in the maintenance of homeostasis and $\mathrm{Pi}$ concentration, modifying $\mathrm{Pi}$ reabsorption in the proximal tubule, where three types of sodium/phosphate co-transporters ( $\mathrm{NaPi}$ co-transporters) have been identified. $\mathrm{NaPi}$ co-transporter 2 is crucial for the Pi reabsorption, modulated by several hormonal and non-hormonal factors as well (Shaman and Kowalski, 2016). Parathyroid hormone (PTH) and $1,25(\mathrm{OH})_{2} \mathrm{D}$ (active form of vitamin D) are the two most important hormones for maintaining $\mathrm{Ca}$ levels in the body. PTH secretion is stimulated by hypocalcaemia, working through three mechanisms to increase $\mathrm{Ca}$ levels: decreasing urinary loss of $\mathrm{Ca}$ by stimulating its reabsorption, stimulating $\mathrm{Ca}$ absorption in the small intestine by stimulating synthesis of $1,25(\mathrm{OH})_{2} \mathrm{D}$ in the kidney, and stimulating the release of $\mathrm{Ca}$ from bone, in part by stimulating bone resorption. As kidney function decreases and the levels of serum $\mathrm{Pi}$ elevate, the conversion of $24(\mathrm{OH}) \mathrm{D}$ to $1,25(\mathrm{OH})_{2} \mathrm{D}$ (calcitriol) is inhibited, causing serum Ca levels to fall and secretion of PTH to increase (secondary hyperparathyroidism, SHPT). SHPT contributes to abnormal bone metabolism observed in CKD and development of renal bone disease (renal osteodystrophy). When in severe form, SHPT may be resistant to dietary/dialytic/pharmacological therapy and persist following transplantation. The bone-disease component of CKD-mineral bone disorder (CKD-MBD) may result in fractures, bone pain, deformities in growth (children), reduced growth velocity, abnormal height, and complications of hip fractures. Surrogate outcomes are bone density and findings on bone biopsies as well as serum biochemical markers of bone resorption and formation. The patients with more advanced stages of CKD (stages 3-5D), in whom biochemical abnormalities of mineral metabolism are present, have renal osteodystrophy. Four types of bone phenotypes/renal osteodystrophy can be diagnosed: osteitis fibrosa cystica, osteomalacia, adynamic bone disorder and mixed osteodystrophy (Moe et al., 2006). In pre-dialysis patients, high bone-turnover (BT) bone disease is most prevalent, while in dialysis patients, low BT, resulting from oversuppression of PTH and high Ca dialysate concentrations. To this condition, the acidosis, suppressive effect of phosphate retention on renal $1,25(\mathrm{OH}) 2 \mathrm{D}$ synthesis and the absence of physiologic inhibitory effect of vitamin D on PTH secretion contribute also.

For the treatment of HP in CKD patients (stages 35(D)), maintaining of serum $\mathrm{Pi}$ and $\mathrm{Ca}$ in the normal ranges is suggested and in addition, phosphate-binders (PBs) to be used. The choice of PB should consider CKD stage, presence of other components of CKD-MBD, concomitant therapies and side-effect profile. Restricted dose of Ca-based phosphate binders (CPBs) is recommended in the presence of persistent or recurrent hypercalcemia (HC), arterial calcification and/or adynamic bone disease, when the serum PTH levels are persistently low. In patients with CKD stage $5 \mathrm{D}$, the longterm use of Al-containing PBs (APBs) should be avoided to prevent Al intoxication. Treatment of abnormal PTH levels in CKD-MBD includes any or all of the following: reducing dietary phosphate intake and administering PBs, Ca-supplements, calcimimetics (CMs) and/or vitamin D analogs, depending on the CKD stage and changes in PTH levels. In patients with CKD stages 3-5D and severe hyperparathyroidism, who fail to respond to pharmacological therapy, parathyroidectomy is suggested. In patients with CKD stages 1-3 with osteoporosis and/or high risk of fracture, management as for the general population is recommended. In patients with CKD stages 4-5D, having biochemical abnormalities of CKD-MBD and low BMD and/or fragility fractures, antiresorptive agents are recommended, with bone biopsy prior to therapy. In addition, for children and adolescents with CKD stages 2-5D and related height deficits, treatment with recombinant human growth hormone could be prescribed when additional growth is desired.

The same regulatory mechanisms affecting bone formation and growth are involved in vascular calcification/coronary artery calcification (VC/CAC) in $\mathrm{CKD}$, a process characterized by thickening and loss of elasticity of muscular arteries walls. $\mathrm{Pi}$ stimulates osteochondrogenic transformation of vascular smooth muscle cells (VSMCs), producing matrix vesicles that regulate mineralization in the vascular intima and media. When elevated, it provokes VC through reductions in osteoclast activity. Other cell types, such as monocytes and macrophages, have also potential to generate mineralized matrix and undergo osteoblastic differentiation, resulting in calcified deposits. SHPT is also a risk factor and in addition, the renin-angiotensinaldosterone system (RAAS) plays role in medial artery calcification (Armstrong et al., 2011). Medial artery calcification is more common in patients with CKD, but atherosclerotic one in the intima may also occur, with inflammatory mediators and elevated lipid content within 
atherosclerotic lesions inducing osteogenic differentiation of VSMCs (Abedin et al., 2004).

$\mathrm{VC} / \mathrm{CAC}$ is associated with many adverse clinical outcomes, including ischemic cardiac events and all-cause cardiovascular mortality, which emphasize the necessesity of preventing or reversing $\mathrm{VC} / \mathrm{CAC}$ to increase the survival in patients with CKD. Ca-channel blockers, hormonal therapy, $\mathrm{PBs}$, and most recently medicinal supplements have all been suggested to reduce progression of VC/CAC. Several studies evaluate the effect of statins (e.g. atorvastatin) (Arad et al., 2005) or RAAS inhibitors (Maahs et al., 2007) on VC/CAC progression, however, with variable success. Other treatments include percutaneous coronary interventions, balloon angioplasty and stents, devices to improve vessel compliance and coronary artery bypass graft surgery as well.

\section{Management of hyperphosphatemia in CKD patients}

Rising serum $\mathrm{Pi}$ levels are almost universally observed in stage 3 CKD patients. However, SHPT often begins to distort bone architecture earlier before $\mathrm{Pi}$ is noted to be abnormal, indicating that the management of factors that are responsible for the intake and removal of phosphate from the body needs to be initiated when eGFRs have declined $<50 \mathrm{~mL} / \mathrm{min} / 1.73 \mathrm{~m}^{2}$. Serum $\mathrm{Pi}$ levels should be maintained between 0.87 and 1.49 $\mathrm{mmol} / \mathrm{L}$ (stage 3-5), and between 1.13 and $1.78 \mathrm{mmol} / \mathrm{L}$ (stage 5). Patients who are on dialysis should have Pi level maintained between 1.13 and $1.78 \mathrm{mmol} / \mathrm{L}$ (K/DOQI Guidelines, 2002).

There are several strategies for correcting HP: restricting dietary phosphate intake, enhancing elimination (with adequate dialysis) and raising serum $\mathrm{Ca}$ concentration to suppress PTH or to increase sensitivity of the calcium-sensing receptors (CaSRs) expressed by the parathyroid gland, and minimizing phosphate absorption (using PBs). Reducing the daily phosphate intake can be complicated due to incompatibility with the recommended daily protein intake, the necessity of intensive patient education, the complexity of dietary tables as well as the substantial variability of phosphate contents in food of the same category. However, when combined with other strategies, dietary modifications can assist in reducing the risk of HP. The rate and extent of phosphate removal depends on the type of dialysis performed. A standard $4 \mathrm{~h}$ HD treatment removes between 600 and $1200 \mathrm{mg} /$ day compared to continuous ambulatory peritoneal dialysis (PD) that removes between 300 and $460 \mathrm{mg} /$ day. Full dialyzer clearance is effective in only the initial phase of the dialysis treatment (first 60-90 min). Afterwards, the transfer rate for phosphate from the intracellular space to the plasma becomes the rate-limiting step for phosphate transport. After dialysis, a significant rebound of phosphate can occur resulting in a potential return to the pre-dialysis $\mathrm{Pi}$ concentrations. As the most practical way to increase Pi removal, the extension of dialysis time is suggested (Daugirdas, 2015). Attention to dialysis efficiency should be also paid.

Nevertheless, the dialysis treatments are usually ineffective in managing HP even when combined with dietary phosphate restriction. Therefore, most dialysis patients require $\mathrm{PB}$ to control their $\mathrm{HP}$, as shown in a prospective cohort study in which 1 -yr all-cause mortality among HD patients $(n=10,044)$ treated with PBs was evaluated (Isakova et al., 2009). PBs work by binding dietary phosphate and forming insoluble complexes that are excreted by the gut.

Given the reduced 1-hydroxylation of vitamin D by the failing kidney, vitamin D and its related compounds may be needed to raise the serum $\mathrm{Ca}$ concentration sufficiently to suppress PTH. In addition, patients can also be given CMs, agents which increase the sensitivity of the CaSRs by down-regulating PTH secretion and reducing hyperplasia of the parathyroid gland.

\section{Phosphate binders}

The most commonly utilized PBs are: CPBs, APBs and non-calcium-based binders (NCPBs) (Table 1). CPBs have historically been a first choice, addressing hypocalcaemia also. However, CPBs can induce HC, which increases the tissue/vascular calcium deposition, especially when combined with vitamin D. NCPBs are alternatives to $\mathrm{CPBs}$ when $\mathrm{HC}$ is present, with different phosphate-binding capacity, pill burden and with generally high prices. The evidences suggest that no one binder is effective and acceptable to every patient, recommending a combination of binders to control the $\mathrm{Pi}$ levels and to minimize the disadvantages of any specific one (Table 2).

\section{Calcium-based phosphate binders}

Of the available CPBs, calcium carbonate (CC) and calcium acetate (CA) are the most widely prescribed medicines. Other PBs that contain $\mathrm{Ca}$ but are much less used include Ca-alginate (25\% elemental $\mathrm{Ca})$, calcium citrate (CCT), calcium gluconate, calcium lactate and calcium ketoglutarate. None of these has any advantage over CC or CA. CCT, for example, is a particularly poor $\mathrm{PB}$ due to competition with $\mathrm{Pi}$ to bind $\mathrm{Ca}$. In addition, soluble citrate salts markedly increase gastrointestinal absorption of trace elements, incl. Al, thus greatly elevating the risk of aluminum toxicity if its salts are ingested.

CPBs are not particularly effective binders at low $\mathrm{pH}$ values because hydrogen ions compete with $\mathrm{Ca}$ for phosphate. They dissociate best in an acid milieu and therefore a noteworthy problem with them is the opposing effects of $\mathrm{pH}$ on solubility and on the Ca-phosphate 
reaction. Large doses are usually required to achieve adequate phosphate management, contributing to continued $\mathrm{Ca}$ overload, positive $\mathrm{Ca}$ balance, increases in serum $\mathrm{Ca}$ levels, and more episodes of $\mathrm{HC}$, adynamic bone disease, and diminished bone buffer capacity. This is of particular concern when they with vitamin D are prescribed (Rees and Shroff, 2015).

The increase in total body $\mathrm{Ca}$ load potentially increases the risk of cardiovascular and other soft tissue calcification. As recent review of Mason and Shepler (2010) points, seven of nine studies report a statistically significant increase in $\mathrm{VC}$ in patients taking CPBs (measured by artery calcification and aortic calcification (AAC) scores). In order VC to be limited, the daily intake of elemental $\mathrm{Ca}$ from dietary sources and from PBs should not exceed twice the daily recommended intake for age ( $2.5 \mathrm{~g}$ /day). Ca from CA is less absorbable than from CC, it has a slightly higher binding capacity (45 vs. $39 \mathrm{mg} / \mathrm{g}$ ), similar relative phosphate-binding coefficient (1.0), but phosphate binder equivalent dose of 0.67 .

There are multiple studies comparing the efficacy and safety of CC with CA. In a large meta-analysis of randomized controlled trials (RCTs) and quasi-RCTs involving adult patients with maintenance HD ( $n=625)$, the Pi was significantly lower in CA group after 4 weeks' (MD -0.15 mmol/L, 95\%CI: -0.28 to -0.01 ) and 8 weeks' administration (MD $-0.25 \mathrm{mmol} / \mathrm{L}, 95 \% \mathrm{CI}$ : -0.40 to 0.11 ), respectively. No difference in serum $\mathrm{Ca}$ levels or the incidence of $\mathrm{HC}$ between the $\mathrm{CC}$ and $\mathrm{CA}$ groups was observed or statistical difference in PTH levels and $\mathrm{Ca} \times \mathrm{P}$ product. However, significantly higher risk of intolerance with CA treatment was observed (RR 3.46; 95\%CI: 1.488.26). No sufficient data were available to establish the comparative superiority on all-cause mortality and cardiovascular end-points (Wang et al., 2015a). Hypercalcaemic effect and phosphate binding power of $\mathrm{CA}$ and $\mathrm{CC}$ in end-stage renal disease (ESRD) patients on maintenance HD was also compared in a randomized control trial conducted in four phases $(n=46)$. Though lower dose of CA was used, it resulted in equally good control of HP as compared to CC therapy (1.37 vs. 1.46 $\mathrm{mmol} / \mathrm{L}, p=0.16)$. Both drugs were well tolerated, but incidence of $\mathrm{HC}$ was higher with $\mathrm{CC}$ (app. 2.73 vs. 2.32 $\mathrm{mmol} / \mathrm{L}, \mathrm{p}<0.01)$. Patients more frequently complained of muscle cramps when taking CA (Saif et al., 2007).

\section{Non-calcium phosphate binders}

NCPBs available currently are magnesium hydroxide $(\mathrm{MH})$ and carbonate $(\mathrm{MC}), \mathrm{AH}$ and aluminum carbonate (AC), sevelamer $\mathrm{HCl}(\mathrm{SH})$ and carbonate (SC), and lanthanum carbonate (LC) (Table 2). An amine functional polymer bixalomer (BX) has been also lunched in Japan (Akizawa et al., 2017). Chewing gum (RenaGum ${ }^{\mathrm{TM}}$ ) formulated with chitosan is another available option. Chitosan released from chewing gum helps to maintain normal Pi levels in CKD patients by binding salivary phosphate in the mouth and gastrointestinal tract (GIT), however, when taken together with other PB and not as substitute (Oh and Uribarri, 2014). A new category of PBs is represented by iron-based compounds, among which ferric citrate hydrate $(\mathrm{FCH})$ or sucroferric oxyhydroxide (SOH). It also includes drugs still under investigation (e.g. iron-magnesium hydroxycarbonate or SBR759 (Schmid and Lederer, 2015). These compounds have demonstrated a phosphate binding efficacy comparable with other NCPBs and NAPBs. However, the long-term safety with respect to iron overload (especially in specific category of patients) and potential interaction with absorption of micronutrients requires further investigation. Other approaches include niacin (NC) (Taketani et al., 2015) and nicotinamide (NA) (Ginsberg and Ix, 2016) in addition to PB therapy. Their beneficial effects (explained by inhibition of the intestinal NaPi co-transporter-2b) were confirmed in 8-week trials in which addition of these drugs to the patient's $\mathrm{PB}$ resulted in lowering of $\mathrm{Pi}$ from 6.66 to $5.96 \mathrm{mg} / \mathrm{dL}$ and from 6.45 to $5.28 \mathrm{mg} / \mathrm{dL}$ in the NC (Edalat-Nejad et al., 2012) and NA treated patients (Cheng et al., 2008), respectively. Additional data on their safety and efficacy are required before widespread clinical use.

The mechanism(s) by which some of NCPBs manifest their action and slow down progression of $\mathrm{VC}$ are not completely clarified. In the novel findings, reduction in elevated bone derived fibroblast growth factor 23 (FGF23) levels is emphasized (Giachelli, 2017). FGF23 has been identified as an important risk factor for cardiovascular diseases, being associated with left ventricular hypertrophy $(\mathrm{LVH})$, activation of the RAS, increased $\mathrm{Na}$ absorption in the renal distal tubules, with subsequent $\mathrm{Na}$ retention and volume expansion, increased markers of inflammation and oxidative stress. There is possibility that FGF23 increases renal phosphate excretion by down-regulating the $\mathrm{NaPi}$ co-transporter in the proximal tubules, thereby increasing Pi secretion (at least in early CKD). In addition, FGF23 suppresses $1 \alpha$ hydroxylase and increases 24-hydroxylase activity, leading to reduced production and increased degradation of $1,25(\mathrm{OH})_{2} \mathrm{D}$ and consequently to SHPT, altered mineral levels, increased bone remodeling, VC and further FGF23 production (Kuro-o, 2010).

\section{Magnesium-based phosphate binders}

Mg-based binders (MPBs) (MH and MC) have been used as alternatives to $\mathrm{CPBs}$, being effective and inexpensive agents in combination with a low dialysate $\mathrm{Mg}$ concentration. $\mathrm{MC}$ is generally better-tolerated and effective in controlling $\mathrm{Pi}$ while reducing elemental $\mathrm{Ca}$ ingestion (Hutchison and Wilkie, 2012). Comparing to CPBs, both drugs are less effective and the larger doses required frequently lead to development of hypermagnesemia (and diarrhea). This disfavors their use, as CKD and particularly ESRD is the only clinical condition where sustained hypomagnesaemia may occur with positive net Mg balance (Spiegel, 2011). According 
to the literature data (Helal et al., 2016), MPBs offer an interesting therapeutic option as adjuncts to CPBs, helping dialysis patients to achieve K/DOQI and KDIGO targets and being a valuable alternative for patients with $\mathrm{HC}$ or poor tolerance to $\mathrm{CC}$. In a cross-over, investigatormasked pilot study, however, in which prevalent PD patients received $\mathrm{CC}$ alone $(200 \mathrm{mg} \mathrm{Ca} / \mathrm{tablet})$ or $\mathrm{CaMg}$ carbonate (CMC) (100 mg Ca, $85 \mathrm{mg} \mathrm{Mg/tablet),} \mathrm{the} \mathrm{dose}$ of CMC used was no better at lowering Pi levels and it was associated with more dose-limiting side effects (Evsanaa et al., 2015).

Moderate hypomagnesaemia, after all, seems to have beneficial effects on VC and mortality in CKD patients. Several observational and small RCTs (supported by several animal studies) suggest that exogenous administration of MPBs may have protective cardiovascular effects in terms of both arrhythmias and VC. This remains controversial and has not been evaluated prospectively. The recent study in a rat model of HP, aimed to compare the effect of MC to that of CA and SC on the development of medial calcification, showed significant reduction in the aortic $\mathrm{Ca}$ content by $\mathrm{MC}$ and $\mathrm{CA}$, but not by SC. The presence of aortic calcification was associated with increased sox 9 , bmp-2, and matrix gla protein expression, without difference in the treatment groups. Ca content in the carotid artery was lower with SC than with CPBs and MPBs, but that in the femoral artery did not differ between the groups (De Schutter et al., 2013). The effect of low dose $\mathrm{CaMg}$ on $\mathrm{VC}$ and possible effects of $\mathrm{CaMg}$ on $\mathrm{BT}$ were also evaluated in chronic renal failure rat. The high phosphorous diet combined with the highest $\mathrm{CaMg}$ dose prevented phosphate depletion and thus the rise in osteoid area, with no effect on osteoblast/osteoclast or dynamic bone parameters and bone $\mathrm{Mg}$ levels. In addition, $\mathrm{CaMg}$ at doses that reduce VC did not show any harmful effect on BT (Neven et al., 2014). The clinical studies have shown that oral $\mathrm{Mg}$ supplementation improves carotid intima media thickness in HD patients, playing an important protective role in the progression of atherosclerosis (Spiegel, 2011). In another study, the use of CaMg-binders over 48 months was associated with a reduction of pulse pressure and left ventricular mass index and with a stabilization of aortic valve calcifications (Matias et al., 2016). In a study of Tzanakis et al. (2014), with stable HD patients randomLy allocated to a regimen containing MC plus CA, Mg probably retarded the arterial calcification. However, no firm proof was obtained that would clarify whether $\mathrm{Mg}$ provides cardiovascular protection to this group of patients. Same was concluded by Spiegel and Farmer (2009), who evaluated the effects of $\mathrm{Mg}$ on $\mathrm{VC}$ and bone mineral density in a small group of chronic HD patients.

\section{Aluminium -based phosphate binders}

Until the mid-1980s, the APBs, AH and to a lesser extent AC, constituted the mainstay of treatment for HP in patients with CKD. Later clinical data pointing to significant accumulation of $\mathrm{Al}$ in the $\mathrm{CNS}$, bone and hematopoietic cells, and the development of severe toxic effects compromised their use. Available historical evidence, however, suggests that the neurological toxicity and $\mathrm{Al}$ bone disease may have primarily

been caused by excessive exposure to $\mathrm{Al}$ in dialysis fluid (Mudge et al., 2011). This was also shown in a study of Arenas et al. (2008), in which the APBs were effective, economical and with an apparent better security profile than in a previous time, due to use of double osmosis inverse in the HD unit and the Al levels in HD liquid less than $2 \mu \mathrm{g} / \mathrm{L}$.

No comparative studies of APBs with different PBs were identified in the PubMed data base in the last 10 years. In previous small short-term studies, in which the effectiveness of AH vs. both CC and CA (Janssen et al., 1996) or sevelamer (Katopodis et al., 2006) was studied, the $\mathrm{AH}$ showed to be more effective than CPBs, while no significant difference in terms of phosphate lowering or side effects was observed when compared with sevelamer. Despite the fact that many thousands $\mathrm{CKD}$ /dialysis patients have received APB over the last decades, there are no recent articles in the PubMed that explore their effects on VC and BT.

\section{Lanthanum carbonate}

LC is a relatively new agent that has been approved as a PB in both pre-dialysis and PD and HD patients, with similar affinity for $\mathrm{Pi}$ as APBs and roughly twice as potent as CPBs and sevelamer (Shigematsu et al., 2012). In comparison with CC (1500-3000 mg/day), LC (750$3000 \mathrm{mg} /$ day) was shown to be equally effective and the only one that decreased serum FGF23 and hepcidin levels (Chang et al., 2016; Soriano et al., 2013). In addition, LC may increase serum bicarbonate concentration, thus correcting the metabolic acidosis and improving clinical outcomes (Beaubien-Souligny et al., 2015). An interim Kaplan-Meier analysis of data from 5-year observational study (ClinicalTrials.gov identifier: NCT00567723) revealed that the median 5-year survival was 51.6 months (95\%CI: 49.1-54.2) in patients who received LC, 48.9 months $(95 \% \mathrm{CI}: 47.3-50.5)$ in patients treated with other PBs and 40.3 months (95\%CI: 38.9-41.5) in patients before the availability of LC. In HD patients, a retrospective cohort study (Kawashima Study) suggested almost $50 \%$ reduction in the mortality rate with oral LC (Tsuchida et al., 2016). Because of the rising trend seen in whole PTH with its administration, the doses of CM and/or vitamin D need to be modulated (Takeuchi et al., 2013).

LC is able to bind Pi efficiently in the low $\mathrm{pH}$ of the stomach as well as in the duodenum and jejunum where higher $\mathrm{pH}$ values exist. Unlike CC, LC is highly insoluble, with only $0.001 \%$ of an oral dose being absorbed in the GIT. In contrast to $\mathrm{Al}$, La does not seem to cross the blood-brain barrier and therefore the potential 
for neurological adverse events is extremely low (Hutchison et al., 2016). However, La may deposit in tissues, particularly bone and liver, although less compared to CC. This was confirmed in a phase III, openlabel study in which the effects on renal osteodistrophy following a baseline bone biopsy were compared (D'Haese et al., 2003). The percentage of patients with adynamic bone, osteomalacia or hyperparathyroidism was reduced by La from 36 to $18 \%$ over one year, while in CC group, increase from 43 to $53 \%$ was observed. The longterm consequences of LC administration on the growing skeleton in humans remains to be evaluated, as short-term studies in rats have shown that $\mathrm{La}$ is deposited into developing bone including the growth plate (Slatopolsky et al., 2005). There was no evidence that La had a direct toxic effect on osteoblasts in a study of Behets et al. (2004). Even more, increased mineralization of the periosteal surface, bone mass within the intracortical resorption spaces and mineralization of the minimodeling surface at the endocortical surface in CKD patients was reported as well as decrease in woven bone volume in cortical bone and increased mineralization of osteons. Although these findings were not observed across all surfaces of the cortical bone in the patients, one expects LC to increase the cortical stability in CKD patients, with consequent reduction in the fracture rate. This is supported by the data from a prospective, open-label study, in which improvement in renal osteodystrophy in Japanese dialysis patients was observed (Shigematsu et al., 2011) and a 2year, randomized, prospective, open-label study showing that similar phosphorus control with standard PB therapy and LC results in higher BT after 1 year and higher bone volume after 2 years (Malluche et al., 2008a).

No evidence of adverse effects of LC on the liver in patients who received treatment for up to 6 years was found (Hutchison et al., 2009), although a case of a woman with pre-existing liver disease, who presented with acute liver failure after introduction of LC was described (De Leeuw et al., 2008). In novel studies, La deposition in gastrointestinal mucosa was observed (Hattori et al., 2017; Hoda et al., 2017; Murakami et al., 2017; Shitomi et al., 2017). Fifteen cases of histiocytic aggregation with crystalloids and one case of duodenitis with histiocyte aggregation without crystalloids have been detected in 30 patients treated with LC (Hattori et al., 2017). The proposed mechanism for gastric lanthanosis is that LC dissolves in the gastric juice, crystallizes within the mucosa and is phagocytized by histiocytes (Tonooka et al., 2015).

LC does not appear to have any additional benefits on VC, inflammation and lipid metabolism. Although superiority in reducing the incidence of hypocalcaemia compared to CPBs was observed (Inaba et al., 2015; Zhai et al., 2015), evidences are provided of a positive effect of LC on the progression of $\mathrm{VC}$ in patients on dialysis (Manabe et al., 2013; Ohtake et al., 2013). In the RCT evaluating the effects of LC and $\mathrm{CC}$ on vascular stiffness in Japanese type 2 diabetes HD patients, it was reported that 2-year treatment with LC might have slowed the progression of brachial-ankle pulse wave velocity (PWV), but with no difference compared to CC (Wada et al., 2015). In another trial, however, LC was associated with reduced progression of aortic calcification compared to CC over 18 months (Toussaint et al., 2011). Wilson et al. (2009) suggested survival benefit associated with LC treatment for patients aged $>65$ years, who are likely to carry the greatest burden of $\mathrm{VC}$.

\section{Iron-based phosphate binders}

Iron in IPBs either adsorbs Pi in the intestinal lumen or reacts with phosphate forming iron phosphate in a chemical reaction that is favored by low $\mathrm{pH}$ value (in the stomach) (Yaguchi et al., 2016). In addition, iron may modulate FGF23 metabolism, which was confirmed in $\mathrm{HD}$ and non-HD CKD patients treated with $\mathrm{FCH}$ (Yokoyama et al., 2014a,b,c; 2012). However, application of IPBs might be accompanied by an increase in serum iron, making them contraindicated in patients suffering from important hepatic or gastric diseases or with a history of hemochromatosis or other disorders caused by iron accumulation. This was observed in a post hoc analysis of a randomized, 24-week phase 3 study and its 28-week extension aimed to evaluate the long-term effect of SOH on iron parameters (Covic et al., 2017).

Ferric citrate (FC) may be more suitable for the treatment of chronic HP in CKD patients requiring iron supplements, as citrate unlike $\mathrm{SOH}$ facilitates iron absorption as well as absorption of the erythropoiesisstimulating agents (ESAs). This was evidenced in lot of studies, in which FC 1.5-6.0 g/day controlled Pi concentrations and reduced the need for ESAs and intravenous iron in patients receiving HD (Nakanishi et al., 2016; Tanaka et al., 2016; Yokoyama et al., 2014a,b,c; 2012). Subjects on dialysis treated with FC received less intravenous elemental $\mathrm{Fe}$ (median=12.95 mg/wk FC; $26.88 \mathrm{mg} / \mathrm{wk}$ active control; $\mathrm{p}<0.001)$ and less ESA (median epoetin-equivalent units per week: 5306 units/wk FC; 6951 units/wk active control; p=0.04), with hemoglobin levels being statistically high (Lewis et al., 2015). Also, oral FC $750 \mathrm{mg} /$ day improved iron stores without inducing overload in iron-deficient HD patients (Tanemoto et al., 2017). Similarly, a 56-day treatment moderately increased serum ferritin and transferrin saturation (Lee et al., 2015).

The effect of FC on progression of ectopic calcification, SHPT and bone abnormalities was evaluated in chronic renal failure (CRF) rats where reduced serum $\mathrm{Pi}$ levels, $\mathrm{Ca} \times \mathrm{P}$ product and $\mathrm{Ca}$ content in the aorta was observed. Serum intact PTH levels and the incidence and severity of parathyroid hyperplasia were also decreased, while femoral bone fibrosis, porosity and osteoid formation reduced (Iida et al., 2013). No such data from clinical trial are available in the PubMed data base. 
There is a possibility oral FC to solubilize $\mathrm{Al}$ present in food and drinking water and open the tight junctions in the intestinal epithelium, thereby increasing its absorption and urinary excretion. However, the results from an openlabel, 52-week, phase III RCT in maintenance dialysis patients with Pi levels $\geq 6.0 \mathrm{mg} / \mathrm{dL}$ showed no evidence of Al toxicity and protein-energy wasting/inflammation (van Buren et al., 2015). Negligible oxidative stress induced by FC formulation in CKD-MBD was observed by Tanaka et al. (2016).

SOH was approved by FDA in 2013 and by EMA in 2014 for treatment of HP in CKD patients receiving dialysis. Several clinical studies and retrospective analysis have been carried out in recent years confirming its longterm efficacy, safety and non-inferiority, lower pill burden and better adherence compared to sevelamer for controlling $\mathrm{Pi}$ in patients undergoing HD or PD (Floege et al., 2014; 2015a; 2017; Geisser and Philipp, 2010). SOH decreased Pi levels starting at 1 wk of treatment when administered as one 250- $\mathrm{mg}$ tablet three times/day, demonstrating a dose-dependent effect up to $3000 \mathrm{mg} /$ day (Koiwa et al., 2017a,b). First prescription of SOH in adult HD patients was associated with an increase in the proportion of patients achieving Pi levels $\leq 5.5 \mathrm{mg} / \mathrm{dL}$, along with fewer prescribed pills/day (Coyne et al., 2017). Similar results were observed in a recent international multicentre study showing this drug to be as efficacious and non-inferior to SC in magnitude of Pi control, with Pi-lowering effect being maintained over 1 year (Bataille et al., 2017).

Early studies on the effect of SOH on VC (in uraemic rats) pointed to reduced progression compared to $\mathrm{CC}$ (Cozzolino et al., 2014). In a similar study, conducted in adenine-induced chronic RFRs, VCs of the thoracic aorta were decreased by all three examined PBs, SOH, LC and SC. However, calcifications were better prevented at the superior part of the thoracic and abdominal aorta in the SOH treated rats (Phan et al., 2015). In the same animal model, the effects of $\mathrm{SOH}$ on phosphatemia accompanying bone abnormality in CKD-MBD were evaluated, showing significant improvement of osteoid volume in $5 \%$ of the $\mathrm{SOH}$ group, and amelioration of fibrosis volume and cortical porosity in $5 \% \mathrm{SOH}, 2 \% \mathrm{SH}$ and 2\% LC groups (Yaguchi et al., 2017). No clinical studies involving the effects of IPBs/SOH on VC and CKD-MBD were identified in the PubMed data base.

Other Ca-free IPB was initially developed by Ineos Healthcare, Warrington (United Kingdom). It is iron magnesium hydroxyl carbonate (Fermagate), consisted of $\mathrm{Mg}$ and ferric iron held in an insoluble hydrotalcite structure, with carbonate groups present to exchange phosphate over a wide $\mathrm{pH}$ range. The high efficacy of Fermagate comparing with other NCPBs has been demonstrated in vitro (Newton et al., 2007). In addition, in a randomized, double-blind, three-arm, parallel-group study that compared two doses of Fermagate administered 21 days to patients on a stable HD regimen for $\geq 3$ days,
Fermagate showed promising dose dependent efficacy and tolerability compared to placebo (McIntyre et al., 2009). Alpharen Tablets (Fermagate tablets) was in phase III development in USA and EU (RCTs were terminated in 2010 for commercial reasons). So far, the evaluation of long-term safety in HD subjects with HP points to control of elevated $\mathrm{Pi}$ at least as well as sevelamer and $\mathrm{La}$, without unwanted heavy metal accumulation in the bone. Lower dosage by nearly $40 \%$ than that of sevelamer, reduced "pill burden" and increased dosing compliance are considered as an advantage.

\section{Sevelamer}

The specific structure of sevelamer and its physicochemical properties (hydrophilic but water insoluble cationic hydrogel) reserve its place among the agents for HP management in CKD. Its efficacy was originally confirmed in several trials [Treat-to-Goal (Chertow et al., 2002), Renagel in New Dialysis (Block et al., 2005)], showing that treatment for up to 52 wks significantly reduces $\mathrm{Pi}$ levels in HD patients and has a minimal effect on serum Ca levels. In addition, sevelamer has confirmed its efficacy in patients with HP secondary to tumor lysis syndrome (Kahlon et al., 2016). Being too large to be absorbed from the GIT, sevelamer swells in intestinal fluids, thus binding negatively charged phosphate anions on protonated amine groups, optimally at $\mathrm{pH}$ 6-7.

$\mathrm{SH}$ was the first member of its class to be marketed, while SC developed as an improved, buffered form, with similar structure. Both are marketed as $800 \mathrm{mg}$ tablets, but a powdered form of SC is also available in many countries (beneficial especially for the elderly and pediatric populations and patients on polytherapy). Not inducing metabolic acidosis (relevant for $\mathrm{SH}$ due to $\mathrm{HCl}$ content) (Oka et al., 2014; Sanai et al., 2015), SC seems to be equivalent to $\mathrm{SH}$ in terms of efficacy and tolerability (Coppolino et al., 2015; Yang et al., 2016). Once-daily administration of SC powder decreases Pi levels significantly (although not as effective as thrice-daily administration of $\mathrm{SH}$ tablets), reaching the KDOQI phosphorus target in most patients (Fishbane et al., 2010). In several studies bicarbonate levels improved only with SC treatment, being more appropriate for patients at risk for metabolic acidosis who require $\mathrm{PB}$ other than $\mathrm{CPB}$ or APB (Fan et al., 2009; Pai and Shepler, 2009). SC has been also significantly better tolerated than $\mathrm{SH}$ in a double-blind, randomized, crossover study evaluating HD patients for 16 wks, where the frequency of GI adverse events was approximately half for SC than that of $\mathrm{SH}$ (Delmez et al., 2007). Both sevelamers, however, as other resin-based binders, can crystallize leading to formation of concretions, with diabetic patients and those with GI mucosal injury being more prone (Kim et al., 2016; Yuste et al., 2017). Rare cases of acute inflammation, ulceration and colon perforation associated with crystal fragments were reported (Desai et al., 2016; Yamaguchi et al., 2016), leading to a theory of physical stimulation at the 
already vulnerable site. The trends for intestinal perforation were examined among US dialysis patients (exposure 2.7 million patient-years) where 4.6 and 2.9 episodes per 1,000 person-years, respectively, were detected, with no significant changes in the incidence before $v s$. after approval of SH (Yang et al., 2013).

Compared to traditional CPBs, definitive advantages of sevelamer have not been demonstrated. The Dialysis Clinical Outcomes Revisited (DCOR) trial that compared the effects on mortality and hospitalization in HD patients suggested that treatment with sevelamer did not affect overall mortality (primary outcome), cause-specific mortality, morbidity, or first or cause-specific hospitalization (secondary outcomes). Beneficial effect on multiple all-cause hospitalizations and hospital days (secondary outcomes) was observed (St Peter et al., 2008). A study designed to compare the efficacy and acceptability of $\mathrm{SH}$ to $\mathrm{CA}$ in pediatric patients with $\mathrm{CKD}$ stages 3 and 4 showed no significant difference in mean $\mathrm{Pi}$ levels (5.3 vs. $6.1 \mathrm{mg} / \mathrm{dL})$. However, the adjusted blood level of $\mathrm{Ca}$ was significantly lower in the sevelamertreated patients $(8.2$ vs. $9.1 \mathrm{mg} / \mathrm{dL})$. Non-significant decrease in serum bicarbonate and significant decrease in total and LDL cholesterol in the sevelamer group was observed (Gulati et al., 2010).

Unlike many studies that favor NCPBs, in a prospective 42-month survival analysis study on 1347 HD patients, $\mathrm{CC}$ use was found to be associated with less mortality (HR, 0.64 [0.4-0.78]) (HR, 1.13 [0.92-1.3]) and more favorable effect on survival than sevelamer use (Jean et al., 2011). In a study of clinically stable CKD stages 3/4 patients, treatment with both $\mathrm{CA}$ and sevelamer reduced similarly the serum PTH and urinary phosphate, with no changes in serum Ca or Pi (Oliveira et al., 2010). However, significantly more frequent $\mathrm{HC}$ episodes with CA were detected in the Calcium Acetate Renagel Evaluation (CARE) study (Qunibi et al., 2008).

Sevelamer has also been shown to be effective in controlling PTH-induced bone disease, without increasing serum Ca levels during therapy with active vitamin D sterols. Several studies match this effect with the one of $\mathrm{CC}$ and CA. In a study, in which pediatric PD patients with SHPT were randomLy assigned to CC or sevelamer for 8 months together with intermittent doses of oral calcitriol or doxercalciferol, bone formation rates improved in both treatment groups, reaching the normal range in about $75 \%$. Serum $\mathrm{Ca}$ levels and $\mathrm{Ca} \times \mathrm{P}$ product remained unchanged with sevelamer (unlike increased in the CC group). In an 8-week, prospective, open-label, randomized study conducted in patients with hypoparathyroidism, the CA treatment decreased serum iPTH unlike sevelamer (Lin et al., 2010), confirming the previous finding for sevelamer in HD patients with low BT osteodystrophy and hypoparathyroidisms, where the iPTH secretory response was enhanced and BT improved as a result of reduced Ca load (Kokuho et al., 2007). In a post hoc analysis of data from the TTG study, the treatment with Ca salts, but not sevelamer was associated with an unexpected reduction in thoracic trabecular and cortical bone attenuation (Raggi et al., 2005). Similarly, in a study of Ferreira et al. (2008), bone formation increased and trabecular architecture improved with sevelamer treatment, with no significant changes in BT or mineralization compared to $\mathrm{CC}$.

An increasing body of evidence suggests that sevelamer also attenuates the progress of coronary and aortic calcification. In the TTG study ( $n=200$ HD patients), reduction in calcification score for the coronary artery and aorta was significantly greater with sevelamer compared to CPBs; this difference was observed as early as 6 months and continued to be significant at 1 year. Similar findings were reported by Block et al. (2005) in patients new on dialysis with mild $\mathrm{CAC}$ at baseline, where treatment with a CPB (mean dose elemental $\mathrm{Ca} 2.3 \mathrm{~g} /$ day) resulted in more rapid progression of CAC compared to sevelamer (mean dose $8 \mathrm{~g} /$ day). Also, in a study of Takei et al. (2008), sevelamer allowed a better control in progression of aortic calcification compared to CPB; the mean changes in aortic calcification index were $3.6 \%$ and $8.2 \%$ in the sevelamer and $\mathrm{Ca}$ group, respectively. A meta-analysis of 31 RCTs supports this finding, identifying a significant difference in the change of CAC scores (by -102.66) and aortic calcification scores (by 1008.73) between sevelamer and CPBs. Prevalence of HC was significantly smaller for sevelamer, with no significant difference in hospitalization, all-cause mortality or cardiovascular mortality (Wang et al., 2015b). Same was confirmed in a study of Kakuta et al. (2011), in which 183 adults (aged >20 years) on maintenance HD were included. Percentages of patients with $\mathrm{a} \geq 15 \%$ increase in CAC score were $35 \%$ in the sevelamer group and $59 \%$ in the CC group $(p=0.002)$. The effect of CC or sevelamer on the progression of calcification was studied in predialysis patients also $(n=90)$ during 2 years. The total $\mathrm{Ca}$ score significantly increased in patients on the low-phosphorus diet alone, to a lesser extent in CC-treated patients, and not at all in sevelamer-treated patients. The progression of coronary calcification parallel to that of the Ca score, suggesting that sevelamer treatment should not be restricted to dialysis patients only (Russo et al., 2007). However, Lemos and colleagues (2013) did not observe delay in the progression of CAC in non-dialysis dependent CKD patients after 24-month treatment with sevelamer $2400 \mathrm{mg} /$ day. In addition, a trial with 120 patients in stage 3 non-diabetic CKD did not provide evidence that SC improves LV mass, LV function, or arterial stiffness (Chue et al., 2013). Also, the results from the Calcium Acetate Renagel Evaluation-2 (CARE-2) study showed that with intensive lowering of LDL-C levels for 1 year (by atorvastatin), HD patients treated with either CA or sevelamer experience similar progression of CAC (Qunibi et al., 2008).

Certain literature data suggest that to reduced progression of VC by sevelamer treatment, its pleiotropic 
effects and FGF23 decrement associated with its use contribute also. Significantly lower LDL-C (from 2.82 to $1.65 \mathrm{mmol} / \mathrm{L}, p=0.000$ ) and FGF23 (from 2465.97 to 795.61, $p=0$ ) and higher s-Klotho levels (from 189.35 to $252.94 \mathrm{pg} / \mathrm{mL}, p=0$ ) after 48-wk sevelamer treatment were observed in a study of Lin et al. (2014), which was not observed in the CC group. Same was detected in a study of Yilmaz et al. (2012) on CKD4 patients where treatment-induced changes in flow-mediated vasodilatation were associated with simultaneous changes in FGF23 levels $(-27.1 \%$ and $3.5 \%$ for the sevelamer and CA group, respectively) as well as with $\mathrm{C}$-reactive protein and fetuin A levels. This is slightly different from the study of Covic et al. (2013), who compared the effects of $\mathrm{CA} / \mathrm{MC}$ and $\mathrm{SH}$ on serum levels of FGF-23 and markers of BT (CALMAG study). The serum levels of FGF-23 were significantly reduced with both $\mathrm{SH}$ and $\mathrm{CaMg}$, with no difference between the groups at wk 25. However, the BT parameters, alkaline phosphatase (AP), bone AP, procollagen type 1 amino-terminal propeptide 1 , osteoprotegerin, beta-crosslaps and tartrate-resistant acid phosphatase $5 \mathrm{~b}$ increased significantly in the $\mathrm{SH}$ group, while remaining almost unchanged in the $\mathrm{CaMg}$ group. Unlike these data, a prospective cohort study examining the effect of Pi reduction with SC in CKD patients did not identify a significant change in plasma FGF23 levels, despite a significant reduction in Pi (Spatz et al., 2013). In addition, in a crossover trial with alphacalcidol and SC in patients with CKD stage 3b, the levels of iFGF23 in patients treated with SC seemed to increase (Bleskestad et al., 2012). This response was mitigated in the group of patients treated by alphacalcidol followed by SC, suggesting therapeutic implications on choice of first line therapy.

Pleiotropic effects of sevelamer were matter of interest in several relevant studies, emphasizing its wide control of factors involved in VC, such as diabetes, dyslipidemia, hyperuricaemia, inflammation and other. Being nonselective anion exchanger, sevelamer exhibits competitive binding to other anions. As it progresses through the intestine, sevelamer binds bile acids and reduces serum levels of glucose and LDL cholesterol at the expense of previously bound phosphate ions, which are released. A lot of studies confirm decrease in total cholesterol, LDL cholesterol and uric acid incl. uremic toxins, with a parallel increase in bone-specific AP (Brønden et al., 2017; Lin et al., 2017). Iimori et al. (2012) evaluated the effects of $\mathrm{SH}$ in a single-center cohort study ( $\mathrm{n}=172$, median 37 months), concluding that reduced mortality in patients with $\mathrm{SH}$ may, at least in part, be explained by an improvement in dyslipidemia and arterial stiffness by SH. All-cause and cardiovascularcause cumulative mortality were significantly lower in the matched sevelamer group than in the control group (CPB or placebo). The matched sevelamer group showed increased HDL cholesterol $(p=0.003)$ and no change in PWP and ankle-brachial index (ABI), whereas the matched control group showed increased serum LDL cholesterol, increased PWV and decreased ABI. Change in serum LDL cholesterol level correlated inversely with SH dosage. In an 8-week, randomized, open-label, parallel-group study comparing the effects of sevelamer and $\mathrm{CA}$ on serum lipid profiles, uric acid and reactive oxygen species in HD patients with HP, total serum cholesterol, LDL cholesterol and serum uric acid decreased significantly in the sevelamer group, with decreases correlating with the reductions in serum $\mathrm{Pi}$ levels. In addition, decreases in plasma $\mathrm{H}_{2} \mathrm{O}_{2}$-related radicals, but not superoxide were observed after sevelamer treatment (Lin et al., 2011). Similarly, in a single-center, randomized, 2-month, open-label, intention-to-treat, crossover study comparing SC with CC treatment in stage 2-4 diabetic CKD, SC reduced $\mathrm{HbA1c}$, serum methylglyoxal, serum $(\varepsilon) \mathrm{N}$-carboxymethyl-lysine, triglycerides and 8-isoprostanes. Total cholesterol and FGF23 were reduced by $\mathrm{SC}$, relative to $\mathrm{CC}$. AGE receptor 1 and sirtuin 1 mRNA were increased and PMNC TNF $\alpha$ levels were decreased by SC, but not by CC. All these data suggest that the effects of sevelamer (SC) on metabolic and inflammatory abnormalities in type 2 diabetes mellitus may affect progression of early diabetic CKD (Vlassara et al., 2012).

The pleiotropic effects of sevelamer may be partly attributable to the increase in serum $\mathrm{Mg}$ levels caused by the drug itself (Ikee et al., 2016; Rosa-Diez et al., 2016). Moreover, there are studies pointing to ability of sevelamer to increase serum levels of fetuin-A, a negative acute phase protein associated with progression of VC and an increased mortality risk in HD patients. In a randomized prospective study conducted on nondiabetic stage 4 CKD patients with HP, the use of sevelamer led to a significant increase in the fetuin-A concentration with improvement in flow-mediated dilation, whereas no significant difference was observed in the CA group (Caglar et al., 2008). These data are inconsistent with the results obtained by Lin and colleagues (2016), who detected decreased fetuin-A levels after 48-week treatment with both sevelamer and CC, with lower fetuinA decrement in sevelamer group (38.64 vs. $58.02 \mu \mathrm{g} / \mathrm{mL})$. In addition, the sevelamer group had less serum $\mathrm{Ca}$ increment, less iPTH decrement, more ALK-P increment, and more hsCRP and LDL-C decrement, all associated with serum fetuin-A decrement. While, the clinical significance of reducing serum uric acid in CKD patients without gout is still questionable, increase in serum fetuin-A concentration is especially beneficial, knowing that its concentrations are significantly lower in patients on HD and having in regard its bone remodeling effect in the foetus, inhibitory function in Ca phosphate deposition and/or its responsibility for accelerated atherosclerosis in uremia.

Anti-inflammatory effect of sevelamer was recently confirmed by Navarro-González et al. (2011), who demonstrated association between the use of sevelamer in 
HD patients and significant decrease in hs-CRP, interleukin (IL)-6 and sCD14 concentrations. The same was observed in several other studies, where SC decreased serum endothelin-1, plasminogen activator inhibitor-1, CRP and IL-6 in patients on PD with type 2 diabetes mellitus (Chennasamudram et al., 2013; Stinghen et al., 2010). In addition, by reducing the serum endotoxin levels, sevelamer manifested capability to dampen the effects of exposure to soluble bacterial products responsible for activation of inflammation (Kubotera et al., 2013). That was not confirmed, however, in a singlearm study on $36 \mathrm{HIV}$-infected subjects not receiving antiretroviral therapy. Sevelamer did not significantly change markers of microbial translocation, inflammation, or T-cell activation. Nevertheless, levels of soluble tissue factor, LDL cholesterol and oxidized LDL cholesterol decreased significantly and D-dimer levels increased, thus pointing to cardiovascular benefits (Sandler et al., 2014). Similar results were obtained in a single-center, openlabel, prospective, randomized study that compared the clinical efficacy, safety and anti-inflammatory activity of two SH tablet forms in CKD5D patients [Renagel (Genzyme) and its generic equivalent (EMS)] (TzannoMartins et al., 2014).

Using the same mechanism for manifesting pleiotropic effects, sevelamer might also bind lipophilic drugs, such as immunosuppressants and the fat-soluble vitamins D, E and K (Takagi et al., 2010). Vitamin K-deficiency limits activation of the vascular tissue mineralization inhibitor matrix $\gamma$-carboxyglutamate (Gla) protein (MGP) thereby exacerbating VC. In one in vitro study, $\mathrm{SOH}$ and SC were the only binders of the five studied that did not bind vitamin K2 (Neradova et al., 2017). Similarly, investigation on the effects of LC (3000 mg/day) and SC (7200 mg/day) on the bioavailability of oral calcitriol (1 $\mu \mathrm{g}$ at lunch), showed that co-administration of LC with calcitriol had no significant effect on $\mathrm{AUC}_{0-48 \mathrm{~h}}$ and $\mathrm{C}_{\max }$ of serum exogenous calcitriol. In contrast, coadministration with sevelamer was associated with a significant reduction in bioavailability parameters for calcitriol (Pierce et al., 2011). Evidence exists pointing that $\mathrm{SH}$ has the potential to bind folic acid. Namely, when administered to 26 outpatients undergoing HD, 3 months later, serum folic acid levels significantly decreased (baseline vs. 3 months; 5.48 vs. $4.79 \mathrm{ng} / \mathrm{mL}, p<0.05$ ), whereas plasma homocysteine levels significantly increased (baseline vs. 3 months; 50.8 vs. $67.6 \mathrm{nmol} / \mathrm{mL}$, $p<0.01$ ) (Goto et al., 2010). To determine whether serum $\mathrm{Pi}$ varies when sevelamer and $\mathrm{CC}$ are administered concomitantly was also an aim of one cross-over, randomized trial in HD patients $(n=14)$. At the end of the two study periods there was no significant difference in the serum $\mathrm{Pi}(1.50 \mathrm{mmol} / \mathrm{L}$ in the "concomitant" period $v s$. $1.51 \mathrm{mmol} / \mathrm{L}$ in the "separate" period, $p=0.97), \mathrm{Ca}(2.26$ vs. $2.27 \mathrm{mmol} / \mathrm{L}, p=0.64), \mathrm{Ca} \times \mathrm{P}(3.36$ vs. $3.41 \mathrm{mmol} / \mathrm{L}$, $p=0.84)$ and bicarbonate levels (21.5 vs. $21.6 \mathrm{mmol} / \mathrm{L}$, $p=0.81$ ), suggesting that simultaneous administration of
$\mathrm{CC}$ and sevelamer does not decrease phosphate-binding capacity (Ouellet et al., 2010). So, the patients can choose to take their PBs according to their preference. Drug interactions between SH and ciprofloxacin (Kays et al., 2003), enalapril and metoprolol (Burke et al., 2001b), digoxin and warfarin (Burke et al., 2001a), cyclosporine and mycophenolate mofetil (Pieper et al., 2004), iron (Pruchnicki et al., 2002) and cinacalcet (Padhi et al., 2014) were evaluated in separate open-label, randomized, crossover experiments involving between 14 and 32 patients. No alteration in pharmacokinetics for most of the medicines was observed. Exceptions were ciprofloxacin, for which a $48 \%$ reduction in the bioavailability was reported $(n=15)$, cyclosporin (AUC and $C_{\max }$ of one of the metabolites were significantly reduced by app. $30 \%$ and $25 \%$, respectively) and mycophenolate mofetil $(n=18)$, for which reduced AUC by $25 \%$ even after a single dose was observed.

\section{Bixalomer}

$\mathrm{BX}$ is an amine-functional polymer, which decreases the $\mathrm{Pi}$ concentration by binding to phosphate in the GIT, thus inhibiting its absorption into the human body. BX was discovered by Ilypsa, Inc. In April 2006, Astellas and Ilypsa, Inc. entered into a license agreement that grants Astellas exclusive rights to develop and commercialize BX in Japan. Then, Astellas conducted the development of Kiklin ${ }^{\circledR}$ Granules. On June 26, 2012, Astellas launched Kiklin ${ }^{\circledR}$ Capsules, approved for the indication of HP in patients on dialysis with CKD in Japan and also received an approval for a supplemental new drug application of Kiklin ${ }^{\circledR}$ Capsules for the treatment of CKD patients not on dialysis with HP on February 29, 2016.

The superiority of BX (Kiklin ${ }^{\circledR}$ Capsules) to placebo was evaluated in a multicenter, double-blind, randomized, placebo-controlled study for a 4-week treatment period in HD patients with HP, with $\mathrm{SH}$ used as an active comparator. BX showed a significant dose-dependent decrease in Pi levels at all doses compared to placebo. The mean change in Pi levels was $-1.80 \mathrm{mg} / \mathrm{dL}$ with $4.5 \mathrm{~g} /$ day $v s$. $-2.32 \mathrm{mg} / \mathrm{dL}$ in the $\mathrm{SH}$ group under the mean dose of $4.8 \mathrm{~g} /$ day (Akizawa et al., 2014a). A multicenter openlabel study with a 48 -week treatment period to assess the safety and efficacy of long-term BX treatment $(n=248$; initial dose $1.5 \mathrm{~g} /$ day, increased to a max. $7.5 \mathrm{~g} /$ day) resulted in decrease of mean serum Pi level to around 5.5 $\mathrm{mg} / \mathrm{dL}$. Most adverse events and reactions occurred soon after starting administration, and their incidence did not increase during long-term treatment (Akizawa et al., 2013). The efficacy and safety of BX vs. placebo for treatment of HP was also evaluated in predialysis Japanese patients with CKD, in a multicenter, randomized, double-blind phase 3 trial. At the end of 12week treatment, $57.5 \%$ of BX-treated patients achieved target Pi concentrations, mean serum iPTH and FGF23 decreased, and there were no significant changes in corrected serum $\mathrm{Ca}$. The safety and tolerability of BX was 
similar to placebo, while the most common drug-related adverse events were gastrointestinal $(>24 \%$ patients per group). In addition, there was a significant increase in bicarbonate concentrations with $\mathrm{BX} v s$. placebo (Akizawa et al., 2016). The long-term effectiveness and safety of $\mathrm{BX}$ in the same patients was also a matter of interest. A 48-week, multicenter, open-label, phase 3 study was conducted, where patients received $\mathrm{BX}$ at an initial dose of $1500 \mathrm{mg} /$ day, which was titrated to a max. $7500 \mathrm{mg} /$ day depending on patients' Pi responses. Mean Pi concentrations decreased from $5.15 \mathrm{mg} / \mathrm{dL}$ at baseline to $4.58 \mathrm{mg} / \mathrm{dL}$ at week 48 . Most adverse events (nasopharyngitis, constipation and upper respiratory tract inflammation) occurred in the first 12 weeks of treatment, with incidence not increasing by long-term treatment (Akizawa et al., 2017).

Non-inferiority of BX to sevelamer was confirmed in a multicenter, randomized open-label, study in which the primary end-point was serum $\mathrm{Pi}$ on completion of treatment. BX achieved a similar reduction of serum Pi to sevelamer, causing fewer adverse reactions, with lower incidence. In addition, it did not promote acidosis (Akizawa et al., 2014b). Subsequent improvement in chronic metabolic acidosis after changing the treatment from $\mathrm{SH}$ to BX was also observed in a study of Sanai et al. (2015), where after 1 month, the serum $\mathrm{HCO}_{3}{ }^{-}$levels increased from 16.3 to $19.6 \mathrm{mmol} / \mathrm{L}$. Changes in the GI symptoms by the Gastrointestinal Symptom Rating Scale (GSRS) score in long-term HD outpatients with SHassociated GI symptoms who switched to BX were observed in a prospective observational study $(n=114)$. BX was well tolerated and managed HP effectively after switching from SH, being less often associated with GI symptoms (Ito et al., 2014). Similar results were observed in a study of Hatakeyama et al. (2013), where 28 patients were switched from SH to BX (1:1 dose) from July to October 2012. Twelve weeks after the switch, reflux, epigastric fullness, constipation, and metabolic acidosis had improved significantly in the switch group, while other factors, including stomach ache, diarrhea and form of stool, did not. However, in a study of Gen et al. (2014), no significant changes for all five of the evaluation items of the GSRS, before and after the switch to BX from SH in maintenance HD patients were observed. Furthermore, switching resulted in significant reduction in serum $\mathrm{Pi}$ concentration, without significant changes in serum corrected $\mathrm{Ca}$ and whole PTH. Similar results were obtained by Furukawa and colleagues (2014), who did not observe significant changes in corrected $\mathrm{Ca}$, whole PTH or ALP after changing the PB. However, the serum HDL$\mathrm{C}$ concentration decreased and LDL-C increased significantly in SH group (serum TG concentration showed no significant changes), suggesting less beneficial effects of BX on lipid metabolism. The role of BX in control of PTH-induced bone disease and in progress of $\mathrm{VC}$ as well as its potential pleiotropic effects were not specifically studied and/or such reports were not identified in the PubMed database.

Calcium-based vs. non-calcium-based phosphate binders (comparative studies and meta-analyses)

Currently available PBs are associated with different problems, such as induction of a positive $\mathrm{Ca}$ balance and impaired outcomes with CPBs or increased costs with NCPBs. Evidence shows that most PBs are roughly equally effective in lowering serum Pi concentrations in adults compared to placebo. However, not all binders had shown equal safety profiles. A systematic review and meta-analyses performed by Sekercioglu et al. (2017; 2016), including data sources from MEDLINE and EMBASE from January 1996 to April 2016, and the Cochrane Register of Controlled Trials up to April 2016, pointed to significantly lower serum $\mathrm{Pi}$ as compared to placebo (moderate to very low quality of evidence) with sevelamer, lanthanum, CPB, IPB, diet and combinations of active treatments (CPB or sevelamer or lanthanum and combination of $\mathrm{CPB}$ and sevelamer). No statistically significant differences between active treatment categories in lowering serum Pi were found. Sevelamer, lanthanum and diet resulted in lower serum Ca compared to CPB (moderate quality evidence for lanthanum and diet; low quality evidence for sevelamer). IPB, sevelamer and CPB yielded lower PTH levels as compared to lanthanum. In addition, patients with CKD-MBD $(n=8335)$ were randomized to receive CPBs (CA, CCT or $\mathrm{CC}$ ), NCPBs ( $\mathrm{SH}$ or $\mathrm{SC}, \mathrm{LC}, \mathrm{SOH}$ and $\mathrm{FC}$ ) and phosphorus restricted diet, placebo or no treatment. No difference in cardiovascular mortality between CPBs and NCPBs was detected using conventional meta-analysis (RR, 2.54; 95\%CI: 0.67-9.62 low quality evidence). However, higher mortality with CPBs than either sevelamer (RR, 1.89; 95\% CI: 1.02-3.50), moderate quality evidence)] or NCPBs [conventional meta-analysis RR, 1.76 (95\%CI: 1.21-2.56), moderate quality evidence] was evidenced as well as non-significant higher hospitalization [RR, 1.293 (95\%CI: 0.94-1.74), moderate quality evidence]. These findings provoked the authors to raise question whether administration of $\mathrm{CPB}$ as an intervention for CKD-MBD remains ethical.

Jamal et al. (2013) performed a systematic review of articles published in any language between Aug 1, 2008 and Oct 22, 2012, by searching Medline, Embase, International Pharmaceutical Abstracts, Cochrane Central Register of Controlled Trials and Cumulative Index to Nursing and Allied Health Literature. Analysis of the 11 randomized trials $(n=4622)$ showed that the patients assigned to NCPBs had a $22 \%$ reduction in all-cause mortality compared with those assigned to CPBs [RR, 0.78, (95\%CI: 0.61-0.98)]. In addition, the effects of CPBs on cardiovascular events and VC in CKD patients were compared to NCPBs in a systematic review based upon eight randomized controlled trials and 2873 subjects. The difference in the change in the calcium score from baseline to follow-up among subjects taking 
NCPBs vs. CPBs was -76.35 (95\%CI: -158.25-5.55). However, no significant difference in cardiovascular mortality and CAC was detected (Jamal et al., 2009).

In several meta-analyses comparison of sevelamer with CPBs was matter of interest. Such randomized, controlled trials in CKD stages 3-5D patients $(n=4770$; $88 \%$ on HD) were identified through MEDLINE and the Cochrane Central Register of Controlled Trials by Patel et al. (2016). Patients receiving sevelamer had lower allcause mortality (RR, 0.54; 95\%CI: 0.32-0.93), no significant difference in cardiovascular mortality $(n=2712$; RR, 0.33; 95\%CI: 0.07-1.64) and an increase in combined gastrointestinal events of borderline statistical significance ( $\mathrm{n}=384$; RR, 1.42; 95\%CI: 0.97-2.08). For biochemical outcomes, patients receiving sevelamer had lower total serum cholesterol (MD -20.2 mg/dL; 95\%CI: -25.9 to $14.5 \mathrm{mg} / \mathrm{dL}$ ), LDL-cholesterol (MD -21.6 mg/dL; 95\%CI: -27.9 to $-15.4 \mathrm{mg} / \mathrm{dL}$ ) and $\mathrm{Ca}$ (MD $-0.4 \mathrm{mg} / \mathrm{dL} ; 95 \% \mathrm{CI}$ : 0.6 to $-0.2 \mathrm{mg} / \mathrm{dL})$ and a reduced risk of $\mathrm{HC}(\mathrm{RR}, 0.30$; 95\%CI: 0.19-0.48). At the end of treatment intact PTH was significantly higher for sevelamer (MD $32.9 \mathrm{pg} / \mathrm{mL}$; 95\%CI: 0.1-65.7 pg/mL), while $\mathrm{Pi}$ values showed no significant differences. In the same population of patients $(n=7631)$, no significant reduction in all-cause mortality or $\mathrm{Ca} \times \mathrm{P}$ product with $\mathrm{SH}$ compared to $\mathrm{CPB}$ s was observed. There was a significant reduction in Pi and PTH but a significant increase in the risk of $\mathrm{HC}$ with $\mathrm{CPBs}$ compared to $\mathrm{SH}$. A significant increase in the risk of adverse gastrointestinal events with $\mathrm{SH}$ in comparison to calcium salts was also observed. In addition, compared with CPBs, lanthanum significantly reduced serum $\mathrm{Ca}$ and the $\mathrm{Ca} \times \mathrm{P}$ product, but not Pi levels. According to authors' opinion, there were no sufficient data to establish the comparative superiority of novel NCPBs for patient-level outcomes such as all-cause mortality and cardiovascular end-points (Navaneethan et al., 2011).

Some trials have indicated that CAC progresses more slowly in sevelamer-treated dialysis patients than in those using CPBs. This was confirmed in a randomized trial with parallel-group design in patients on maintenance HD, randomLy assigned to 12-month treatment with sevelamer $(n=91)$ or $C C(n=92)$. Both binders were associated with an increase in mean CAC score. However, the increase in the sevelamer group was less $(\mathrm{p}<0.001)$. In addition, sevelamer suppressed accumulation of circulating advanced glycation end-products (Kakuta et al., 2011).

\section{Other significant medications affecting phosphate}

\section{Active vitamin D sterols}

Active vitamin D sterols (Table 3) are the mainstay of therapy for controlling serum PTH levels and data on their potential benefits in CKD patients, including improved histological abnormalities of bone from SHPT, increased bone mineral density, reduction of elevated PTH levels, improved cardiac systolic function and decreased proteinuria are widely documented (Rauscher et al., 2017; Shroff et al., 2017). While no significant difference in lowering PTH between the different sterols was demonstrated (Ito et al., 2009; Moe et al., 2010), treatment with calcitriol and alfacalcidol in combination with CPBs often results in $\mathrm{HC}$ and $\mathrm{HP}$ which contributes to the development of soft tissue calcification. Newer vitamin D analogues, maxacalcitol, paricalcitol, doxercalciferol and falecalcitriol were developed to minimize intestinal $\mathrm{Ca}$ and phosphorus absorption, while suppressing PTH (Freundlich et al., 2017).

The long-term consequences of therapy with vitamin $\mathrm{D}$ analogues in conjunction with the use of CPBs on vascular calcification and cardiovascular complications are still undetermined. As limited data point out, the newer ones are less likely to promote progression of calcification. A search in MEDLINE, Embase, the Cochrane Library and reference lists for RCTs to compare paricalcitol with placebo in stage 2-5 CKD (including predialysis and renal replacement patients, $n=1894$ ) pointed to reduced risk of cardiovascular events but increased risk of $\mathrm{HC}$ with paricalcitol, without improvement in cardiac structure (Hu et al., 2017). The use of paricalcitol in patients with stages 3-5 CKD, including patients with chronic glomerulonephritis, chronic tubulointerstitial nephritis and hypertensive nephrosclerosis, with PTH hyperproduction, resulted in not only normalization of the levels of both PTH and osseous isoenzyme of AP, but also in significantly reduced daily proteinuria and regression of LVH and chronic heart failure (Milovanova et al., 2014). Similar were findings for maxacalcitol, suggesting that the vasoprotective effects of vitamin D analogues are mediated by reducing oxidative stress (Mizobuchi et al., 2014).

\section{Calcimimetics}

CM (e.g., cinacalcet, etelcalcetide; Table 3) are positive allosteric modulators of the CaSRs in parathyroid glands leading to a reduction in PTH secretion and regression of parathyroid glands proliferation. Cinacalcet inhibits PTH secretion within minutes, with a maximal decrease occurring within 2 hours of dosing in SHPT patients. In adult patients on maintenance dialysis, decrease in FGF23 (probably due to the suppression of osteoblasts function), serum $\mathrm{Ca}$, serum $\mathrm{Pi}$ and the $\mathrm{Ca} \times \mathrm{P}$ product was also observed, regardless of the specific $\mathrm{PB}$ (Sprague et al., 2015; Wesseling-Perry and Salusky, 2013).

Hypocalcemia is easily managed with dose adjustment or a combination with low doses of vitamin D sterols in subjects with moderate to severe SHPT (Khan et al., 2015). In addition, continuing administration of cinacalcet and subsequent metabolism by cytochrome P450 system enzyme results in a cyclical pattern of serum PTH levels, which might have anabolic effects on bone. 
The hypothesis that cinacalcet would reduce the rate of clinical fractures in patients receiving HD was tested using data from the Evaluation of Cinacalcet $\mathrm{HCl}$ Therapy to Lower Cardiovascular Events (EVOLVE) trial, a placebo-controlled trial that randomized 3883 HD patients with SPTH receiving cinacalcet or placebo for $\leq 64$ months. By using an unadjusted intention-to-treat analysis, it was shown that cinacalcet did not reduce the rate of clinical fracture. However, when accounting for differences in baseline characteristics, multiple fractures and/or events prompting discontinuation of study drug, cinacalcet reduced the rate of clinical fracture by $16-29 \%$ (Moe et al., 2015). In the multicenter, single-arm BONAFIDE study that characterized the skeletal response to cinacalcet in adult dialysis patients $(n=110$, plasma PTH $\geq 300 \mathrm{pg} / \mathrm{mL}$, serum Ca $\geq 8.4 \mathrm{mg} / \mathrm{dL}$, bone-specific AP over $20.9 \mathrm{ng} / \mathrm{mL}$, biopsy-proven high-turnover bone disease), the long-term treatment with cinacalcet substantially reduced PTH, diminished the elevated bone formation rate/tissue area, lowered several biochemical markers of high-turnover bone disease toward normal and generally improved bone histology (Behets et al., 2015). Reduced BT and tissue fibrosis among most dialysis patients with biochemical evidence of SHPT was also observed in a study of Malluche et al. (2008b), while in a multicenter, prospective study in which HD patients with poorly controlled SHPT $(n=55)$ were enrolled, cinacalcet increased proximal femur bone mineral density, but did not affect the lumbar spine (El-Shafey et al., 2011). Similar were the findings from the multicentre, open-label study with HD subjects, in which combined therapy with cinacalcet and low doses of vitamin D sterols improved achievement of the biochemical targets for CKD-MBD (Block et al., 2008).

Considering the effect of CMs (cinacalcet) on the progression of $\mathrm{VC}$, the results are inconsistent so far. While experimental studies demonstrated an inhibitory effect on the progression of VC in rodents with CKD and atherosclerosis (Kawata et al., 2008; Wu et al., 2016), the clinical trials demonstrated no difference or favorable effect. When combination of cinacalcet and low dose vitamin D was prospectively compared to flexible doses of vitamin D sterols in the ADVANCE trial, median Agatston CAC scores increased $24 \%$ in the cinacalcet group and $31 \%$ in the flexible vitamin D group. Corresponding changes in volume CAC scores were $22 \%$ and $30 \%$. Increases in calcification scores were consistently less in the aorta, aortic valve and mitral valve among subjects treated with cinacalcet plus low-dose vitamin D sterols, and the differences between groups were significant at the aortic valve (Raggi et al., 2011; Bellasi et al., 2013; Ureña-Torres et al., 2013). In the EVOLVE study, cinacalcet appeared to reduce the incidence of calcific uremic arteriolopathy in HD recipients who have moderate to severe SHPT (Floege et al., 2015b). However, in an unadjusted intention-to-treat analysis cinacalcet did not significantly reduce the risk of death or major cardiovascular events (EVOLVE Trial Investigators, 2012). In addition, the blood calcification propensity was independently associated with the primary composite end point, all-cause mortality, myocardial infarction and peripheral vascular event and improved risk prediction (Pasch et al., 2017). In a study of Nakayama et al. (2013), patients on maintenance HD $(n=25)$ with insufficiently controlled SHPT by conventional therapies were initially administered $25 \mathrm{mg}$ cinacalcet daily, with concomitant use of calcitriol analogs. Serum levels of intact PTH, Pi, Ca and $\mathrm{Ca} \times \mathrm{P}$ significantly decreased, with increase in the aortic calcification area index being significantly suppressed.

Recently, a new long-acting peptide (etelcalcetide) belonging to the CM class was approved for intravenous use in HD patients with SHPT (Cozzolino et al., 2017; Hamano et al., 2017). Two parallel phase 3 randomized placebo-controlled trials were conducted in patients $(n=1032)$ receiving HD with moderate to severe SHPT, at 111 sites in USA, Canada, Europe, Israel, Russia and Australia, from March 12, 2013 to May 12, 2014. Patients randomized to etelcalcetide were significantly more likely to achieve a PTH level of $300 \mathrm{pg} / \mathrm{mL}$ or lower, having more muscle spasms, nausea and vomiting comparing to placebo (Block et al., 2017a,b). Etelcalcetide in HD patients with SHPT was more effective than placebo and cinacalcet, with a PTH reduction of $>30 \%$ in $76 \%$ of patients with etelcalcetide vs. $10 \%$ with placebo. The most common adverse event was asymptomatic blood $\mathrm{Ca}$ reduction, similar to cinacalcet, while GI symptoms were less frequent. There is a possibility, the longer $t_{1 / 2}$ of etelcalcetide to reduce the fluctuation of biochemical markers of mineral and bone metabolism. However, further studies are needed to determine the impact of etelcalcetide on clinical outcomes, particularly in comparison with the conventional CM cinacalcet.

\section{Conclusion}

HP in CKD is as a distinct syndrome characterized by phosphate excretion failure, failure of the skeletal reservoir function, heterotopic mineralization, including the vasculature, and severe cardiovascular disease leading to morbid cardiac events and often to death. In addition, it is a key pathogenic factor in the development of SHPT and precludes its treatment with vitamin D. The corner stone for the management of HP in patients with CKD are PBs and all of them have been found to be equally effective in terms of phosphate control when given in equivalent doses. CPBs are widely available and affordable; however, they cause harmful Ca overload and $\mathrm{VC}$, being not suitable in patients with $\mathrm{HC}$ or dialysis patients with advanced calcifications. Several NCPBs are available, including the non-absorbing agent sevelamer and the absorbing agents, e.g. lanthanum and magnesium salts. They do not appear to increase the risk of HC but 
they are relatively more expensive than CPBs. Some of them have a positive effect on bone disease (e.g. sevelamer, lanthanum) and VC (e.g. sevelamer), for others (e.g. magnesium salts) clear evidence is lacking. In addition, long-term accumulation of $\mathrm{La}$ and $\mathrm{Mg}$ in tissues (including bone) and in this respect, clinically relevant toxic effects have to be explored.

Active vitamin D sterols are the mainstay of therapy for controlling serum PTH levels and research data underline their potential benefits in CKD patients, including improved histologic abnormalities of bone from SHPT, increased bone mineral density, reduction of elevated PTH levels, improved cardiac systolic function and decreased proteinuria. However, the long-term consequences of therapy with vitamin $\mathrm{D}$ analogues in conjunction with the use of $\mathrm{CPBs}$ on $\mathrm{VC}$ and cardiovascular complications are still undetermined. As research data point out, the newer vitamin $\mathrm{D}$ analogues are less likely to promote progression of calcification in cardiovascular tissue. CMs also overcome the stimulatory effect of high phosphate on PTH secretion and they are effective in patients with SHPT whose phosphorus levels contraindicate vitamin D treatment alone. Further studies are needed to determine the impact of CMs on the progression of VC and BT/bone histology.

\section{References}

Abedin, M., Tintut, Y., Demer, L.L., 2004. Vascular calcification: mechanisms and clinical ramifications. Arterioscler. Thromb. Vasc. Biol. 24, 1161-1170.

Akizawa, T., Origasa, H., Kameoka, C., Kaneko, Y., Kanoh, H., 2014a. Dose-finding study of bixalomer in patients with chronic kidney disease on hemodialysis with hyperphosphatemia: a double-blind, randomized, placebocontrolled and sevelamer hydrochloride-controlled openlabel, parallel group study. Ther. Apher. Dial. 18, 24-32.

Akizawa, T., Tsukada, J., Kameoka, C., Kuroishi, K., Yamaguchi, Y., 2017. Long-term safety and efficacy of bixalomer in hyperphosphatemic patients with chronic kidney disease not on dialysis. Ther. Apher. Dial. 21, 173179.

Akizawa, T., Origasa, H., Kameoka, C., Tsukada, J., Kuroishi, K., Yamaguchi, Y., 2016. Bixalomer in hyperphosphatemic patients with chronic kidney disease not on dialysis: phase 3 randomized trial. Ther. Apher. Dial. 20, 588-597.

Akizawa, T., Kameoka, C., Kaneko, Y., Kawasaki, S., 2013. Bixalomer Study Group. Long-term treatment of hyperphosphatemia with bixalomer in Japanese hemodialysis patients. Ther. Apher. Dial. 17, 612-619.

Akizawa, T., Origasa, H., Kameoka, C., Kaneko, Y., Kawasaki, S., 2014b. Bixalomer Study Group. Randomized controlled trial of bixalomer versus sevelamer hydrochloride in hemodialysis patients with hyperphosphatemia. Ther. Apher. Dial. 18, 122-131.

Arad, Y., Spadaro, La., Roth, M., Nestein, D., Guerci, A.D., 2005. Treatment of asumptomatic adults with elevated coronary calcium scores with atorvasttain, vitamin $\mathrm{C}$, and vitamin E. The St. Francis Heart Study randomized clinical trial. J. Am. Coll. Cardiol. 46, 166-172.
Arenas, M.D., Malek, T., Gil, M.T., Moledous, A., Núñez, C., Alvarez-Ude, F., 2008. Use of the aluminum phosphatebinders in hemodialysis in the ultrapure water era. Nefrologia 28, 168-173.

Armstrong, Z.B., Boughner, D.R., Drangova, M., Rogers, K.A., 2011. Angiotensin II type 1 receptor blocker inhibits arterial calcification in a preclinical model. Cardiovasc. Res. 90, 165-170.

Bataille, P., Delattre, V., Daroux, M., 2017. Sucroferric oxyhydroxide, a novel iron-based phosphate binder. Which current use in dialysis patients? Nephrol. Ther. 13 Suppl, S103-S108.

Beaubien-Souligny, W., Bezzaoucha, S., Pichette, V., Lafrance, J.P., Bell, R., Lamarche, C., Ouimet, D., Vallee, M., 2015. The effect of lanthanum carbonate on metabolic acidosis in patients with chronic kidney disease stage IV, V and V-D. Int. Urol. Nephrol. 47, 1165-1171.

Behets, G.J., Dams, G., Vercauteren, S.R., Damment, S.J., Bouillon, R., De Broe, M.E., D'Haese, P.C., 2004. Does the phosphate binder lanthanum carbonate affect bone in rats with chronic renal failure? J. Am. Soc. Nephrol. 15, 2219-2228.

Behets, G.J., Spasovski, G., Sterling, L.R., Goodman, W.G., Spiegel, D.M., De Broe, M.E., D'Haese, P.C., 2015. Bone histomorphometry before and after long-term treatment with cinacalcet in dialysis patients with SHPT. Kidney Int. 87, 846-856.

Bellasi, A., Reiner, M., Pétavy, F., Goodman, W., Floege, J., Raggi, P., 2013. Presence of valvular calcification predicts the response to cinacalcet: data from the ADVANCE study. J. Heart Valve. Dis. 22, 391-399.

Bleskestad, I.H., Bergrem, H., Hartmann, A., Godang, K., Gøransson, L.G., 2012. Fibroblast growth factor 23 and parathyroid hormone after treatment with active vitamin D and sevelamer carbonate in patients with chronic kidney disease stage $3 \mathrm{~b}$, a randomized crossover trial. BMC Nephrol. 28, 13:49.

Block, G.A., Spiegel, D.M., Ehrlich, J., Mehta, R., Linderbergh, J., Dreisbach, A., Raggi, P., 2005. Effects of sevelamer and calcium on coronary artery calcification in patients new to hemodialysis. Kidney Int. 68, 1815-1824.

Block, G.A., Bushinsky, D.A., Cheng, M.S., Cunningham, J., Dehmel, B., Drueke, T.B., Ketteler, M., Kewalramani, R., Martin, K.J., Moe, S.M., Patel, U.D., Silver, J., Sun, Y., Wang, H., Chertow, G.M., 2017a. Effect of etelcalcetide vs cinacalcet on serum parathyroid hormone in patients receiving hemodialysis with secondary hyperparathyroidism: a randomized clinical trial. JAMA 317, 156-164.

Block, G.A., Bushinsky, D.A., Cunningham, J., Drueke, T.B., Ketteler, M., Kewalramani, R., Martin, K.J., Mix, T.C., Moe, S.M., Patel, U.D., Silver, J., Spiegel, D.M., Sterling, L., Walsh, L., Chertow, G.M., 2017b. Effect of etelcalcetide vs placebo on serum parathyroid hormone in patients receiving hemodialysis with secondary hyperparathyroidism: two randomized clinical trials. JAMA 10, 146-155.

Block, G.A., Zeig, S., Sugihara, J., Chertow, G.M., Chi, E.M., Turner, S.A., Bushinsky, D.A., 2008. TARGET Investigators. Combined therapy with cinacalcet and low doses of vitamin D sterols in patients with moderate to severe secondary hyperparathyroidism. Nephrol. Dial. Transplant. 23, 2311-2318. 
Brønden, A., Albér, A., Rohde, U., Gasbjerg, L.S., Rehfeld, J.F., Holst, J.J., Vilsbøll, T., Knop, F.K., 2017. The bile acid-sequestering resin sevelamer eliminates the acute GLP-1 stimulatory effect of endogenously released bile acids in patients with type 2 diabetes. Diabetes Obes. Metab. DOI: 10.1111/dom.13080.

Burke, S., Amin, N., Incerti, C., Plone, M., Watson, N., 2001a. Sevelamer hydrochloride (Renagel), a nonabsorbed phosphate-binding polymer, does not interfere with digoxin or warfarin pharmacokinetics. J. Clin. Pharmacol. 41, 193198.

Burke, S.K., Amin, N.S., Incerti, C., Plone, M.A., Lee, J.W., 2001b. Sevelamer hydrochloride (Renagel), a phosphatebinding polymer, does not alter the pharmacokinetics of two commonly used antihypertensives in healthy volunteers. J. Clin. Pharmacol. 41, 199-205.

Caglar, K., Yilmaz, M.I., Saglam, M., Cakir, E., Acikel, C., Eyileten, T., Yenicesu, M., Oguz, Y., Vural, A., Carrero, J.J., Axelsson, J., Lindholm, B., Stenvinkel, P., 2008. Short-term treatment with sevelamer increases serum fetuin-a concentration and improves endothelial dysfunction in chronic kidney disease stage 4 patients. Clin. J. Am. Soc. Nephrol. 3, 61-68.

Chang, Y.M., Tsai, S.C., Shiao, C.C., Liou, H.H., Yang, C.L., Tung, N.Y., Hsu, K.S., Chen, I.L., Liu, M.C., Kao, J.L., Jhen, R.N., Huang, Y.T., 2016. Effects of lanthanum carbonate and calcium carbonate on fibroblast growth factor 23 and hepcidin levels in chronic hemodialysis patients. Clin. Exp. Nephrol. DOI: 10.1007/s10157-0161362-9.

Cheng, C., Young, D.O., Huang, Y., Delmez, J.A., Coyne, D.W., 2008. A randomized, double-blind, placebocontrolled trial of niacinamide for reduction of phosphorus in hemodialysis patients. Clin. J. Am. Soc. Nephrol. 3, 1131-1138.

Chennasamudram, S.P., Noor, T., Vasylyeva, T.L., 2013. Comparison of sevelamer and calcium carbonate on endothelial function and inflammation in patients on peritoneal dialysis. J. Ren. Care 39, 82-89.

Chertow, G.M., Burke, S.K., Raggi, P., 2002. Sevelamer attenuates the progression of coronary and aortic calcification in hemodialysis patients. Kidney Int. 62, 245252.

Chue, C.D., Townend, J.N., Moody, W.E., Zehnder, D., Wall, N.A., Harper, L., Edwards, N.C., Steeds, R.P., Ferro, C.J., 2013. Cardiovascular effects of sevelamer in stage 3 CKD. J. Am. Soc. Nephrol. 24, 842-852.

Coppolino, G., Lucisano, S., Rivoli, L., Fuiano, G., Villari, A., Villari, I., Leonello, G., Lacquaniti, A., Santoro, D., Buemi, M., 2015. Sevalamer HCl, sevelamer carbonate and lanthanum carbonate: in vitro and in vivo effects on gastric environment. Ther. Apher. Dial. 19, 471-476.

Covic, A., Passlick-Deetjen, J., Kroczak, M., BüschgesSeraphin, B., Ghenu, A., Ponce, P., Marzell, B., de Francisco, A.L., 2013. A comparison of calcium acetate/magnesium carbonate and sevelamer-hydrochloride effects on fibroblast growth factor-23 and bone markers: post hoc evaluation from a controlled, randomized study. Nephrol. Dial. Transplant. 28, 2383-2392.

Covic, A.C., Floege, J., Ketteler, M., Sprague, S.M., Lisk, L., Rakov, V., Rastogi, A., 2017. Iron-related parameters in dialysis patients treated with sucroferric oxyhydroxide. Nephrol. Dial. Transplant. 32, 1330-1338.
Coyne, D.W., Ficociello, L.H., Parameswaran, V., Anderson, L., Vemula, S., Ofsthun, N.J., Mullon, C., Maddux, F.W., Kossmann, R.J., Sprague, S.M., 2017. Real-world effectiveness of sucroferric oxyhydroxide in patients on chronic hemodialysis: A retrospective analysis of pharmacy data. Clin. Nephrol. 88, 59-67.

Cozzolino, M., Funk, F., Rakov, V., Phan, O., Teitelbaum, I., 2014. Preclinical pharmacokinetics, pharmacodynamics and safety of sucroferric oxyhydroxide. Curr. Drug Metab. 15, 953-965.

Cozzolino, M., Galassi, A., Conte, F., Mangano, M., Di Lullo, L., Bellasi, A., 2017. Treatment of secondary hyperparathyroidism: the clinical utility of etelcalcetide. Ther. Clin. Risk Manag. 13, 679-689.

D'Haese, P.C., Spasovski, G.B., Sikole, A., 2003. A multicenter study on the effects of lanthanum carbonate (Fosrenol) and calcium carbonate on renal bone disease in dialysis patients. Kidney Int. Suppl. 85, S73-S78.

Daugirdas, J.T., 2015. Removal of phosphorus by hemodialysis. Semin. Dial, 28, 620-623.

De Leeuw, K., Woestenburg, A., Verbeelen, D., 2008. Lanthanum carbonate possibly responsible for acute liver failure in a patient with Child-Pugh stage A liver cirrhosis. NDT Plus. 1, 412-413.

De Schutter, T.M., Behets, G.J., Geryl, H., Peter, M.E., Steppan, S., Gundlach, K., Passlick-Deetjen, J., D'Haese, P.C., Neven, E., 2013. Effect of a magnesiumbased phosphate binder on medial calcification in a rat model of uremia. Kidney Int. 83, 1109-1117.

Delmez, J., Block, G., Robertson, J., Chasan-Taber, S., Blair, A., Dillon, M., Bleyer, A.J., 2007. A randomized, doubleblind, crossover design study of sevelamer hydrochloride and sevelamer carbonate in patients on hemodialysis. Clin. Nephrol. 68, 386-391.

Desai, M., Reiprich, A., Khov, N., Yang, Z., Mathew, A., Levenick, J., 2016. Crystal-associated colitis with ulceration leading to hematochezia and abdominal pain. Case Rep. Gastroenterol. 27, 332-337.

Edalat-Nejad, M., Zameni, F., Talaiei, A., 2012. The effect of niacin on serum phosphorus levels in dialysis patients. Ind. J. Nephrol. 22, 174-178.

El-Shafey, E.M., Alsahow, A.E., Alsaran, K., Sabry, A.A., Atia, M., 2011. Cinacalcet hydrochloride therapy for secondary hyperparathyroidism in hemodialysis patients. Ther. Apher. Dial. 15, 547-555.

EVOLVE Trial Investigators, Chertow, G.M., Block, G.A., Correa-Rotter, R., Drüeke, T.B., Floege, J., Goodman, W.G., Herzog, C.A., Kubo, Y., London, G.M., Mahaffey, K.W., Mix, T.C., Moe, S.M., Trotman, M.L., Wheeler, D.C., Parfrey, P.S., 2012. Effect of cinacalcet on cardiovascular disease in patients undergoing dialysis. N. Engl. J. Med. 367, 2482-2494.

Evsanaa, B., Liu, I., Aliazardeh, B., Mahdavi, S., Bajwa, G., Gula, J., Tam, M., Sze, E., Roscoe, J.M., Tam, P.Y., Sikaneta, T., 2015. $\mathrm{MgCaCO}_{3}$ versus $\mathrm{CaCO}_{3}$ in peritoneal dialysis patients-a cross-over pilot trial. Perit. Dial. Int. 35, 31-34.

Fan, S., Ross, C., Mitra, S., Kalra, P., Heaton, J., Hunter, J., Plone, M., Pritchard, N., 2009. A randomized, crossover design study of sevelamer carbonate powder and sevelamer hydrochloride tablets in chronic kidney disease patients on haemodialysis. Nephrol. Dial. Transplant. 24, 3794-3799.

Ferreira, A., Frazão, J.M., Monier-Faugere, M.C., Gil, 
C., Galvao, J., Oliveira, C., Baldaia, J., Rodrigues, I., Santos, C., Ribeiro, S., Hoenger, R.M., Duggal, A., Malluche, H.H, 2018. Sevelamer Study Group. Effects of sevelamer hydrochloride and calcium carbonate on renal osteodystrophy in hemodialysis patients. J. Am. Soc. Nephrol. 19, 405-412.

Fishbane, S., Delmez, J., Suki, W.N., Hariachar, S.K., Heaton, J., Chasan-Taber, S., Plone, M.A., Moe, S., 2010. A randomized, parallel, open-label study to compare oncedaily sevelamer carbonate powder dosing with thricedaily sevelamer hydrochloride tablet dosing in CKD patients on hemodialysis. Am. J. Kidney Dis. 55, 307-315.

Floege, J., Covic, A.C., Ketteler, M., Mann, J., Rastogi, A., Spinowitz, B., Rakov, V., Lisk, L.J., 2017. Sprague SM. One-year efficacy and safety of the iron-based phosphate binder sucroferric oxyhydroxide in patients on peritoneal dialysis. One-year efficacy and safety of the iron-based phosphate binder sucroferric oxyhydroxide in patients on peritoneal dialysis. Nephrol. Dial. Transplant. DOI: 10.1093/ndt/gfw460.

Floege, J., Covic, A.C., Ketteler, M., Mann, J.F., Rastogi, A., Spinowitz, B., Chong, E.M., Gaillard, S., Lisk, L.J., Sprague, S.M., Sucroferric Oxyhydroxide Study Group, 2015a. Long-term effects of the iron-based phosphate binder, sucroferric oxyhydroxide, in dialysis patients. Nephrol. Dial. Transplant. 30, 1037-1046.

Floege, J., Covic, A.C., Ketteler, M., Rastogi, A., Chong, E.M., Gaillard, S., Lisk, L.J., Sprague, S.M., PA21 Study Group, 2014. A phase III study of the efficacy and safety of a novel iron-based phosphate binder in dialysis patients. Kidney Int. 86, 638-647.

Floege, J., Kubo, Y., Floege, A., Chertow, G.M., Parfrey, P.S., 2015b. The effect of cinacalcet on calcific uremic arteriolopathy events in patients receiving hemodialysis: The EVOLVE Trial. Clin. J. Am. Soc. Nephrol. 7, 800-807.

Freundlich, M., Abitbol, C.L., 2017. Oral paricalcitol: expanding therapeutic options for pediatric chronic kidney disease patients. Pediatr. Nephrol. 32, 1103-1108.

Furukawa, K., Ikawa, T., Yokoi, S., Yokouchi, S., Kato, K., Ueno, M., Takahashi, J., 2014. Effects of switching from sevelamer hydrochloride to bixalomer on laboratory parameters in hemodialysis patients. Ther. Apher. Dial. 18(Suppl), 2-7.

Geisser, P., Philipp, E., 2010. PA21: a novel phosphate binder for the treatment of hyperphosphatemia in chronic kidney disease. Clin. Nephrol. 74, 4-11.

Gen, S., Sasaki, T., Saito, K., Nobe, K., Nodaira, Y., Ikeda, N., 2014. Clinical effects of the new phosphorus binder, bixalomer in hemodialysis patients switched from sevelamer hydrochloride. Ther. Apher. Dial. 18(Suppl 2), 812

Giachelli, Y.S., 2017. Vascular calcification in CKD-MBD: Roles for phosphate, FGF23, and Klotho. Bone 100, 87-93.

Ginsberg, C., Ix, J.H., 2016. Nicotinamide and phosphate homeostasis in chronic kidney disease. Curr. Opin. Nephrol. Hypertens. 25, 285-291.

Goto, S., Fujii, H., Kim, J.I., Fukagawa, M., 2010. Homocysteine and folic acid levels in hemodialysis patients treated with sevelamerhydrochloride. Clin. Nephrol. 73, 420-425.

Gulati, A., Sridhar, V., Bose, T., Hari, P., Bagga, A., 2010. Short-term efficacy of sevelamer versus calcium acetate in patients with chronic kidney disease stage 3-4. Int. Urol.
Nephrol. 42, 1055-1062.

Hamano, N., Komaba, H., Fukagawa, M., 2017. Etelcalcetide for the treatment of secondary hyperparathyroidism. Expert Opin. Pharmacother. 18, 529-534.

Hatakeyama, S., Murasawa, H., Narita, T., Oikawa, M., Fujita, N., Iwamura, H., Mikami, J., Kojima, Y., Sato, T., Fukushi, K., Ishibashi, Y., Hashimoto, Y., Koie, T., Saitoh, H., Funyu, T., Ohyama, C., 2013. Switching hemodialysis patients from sevelamer hydrochloride to bixalomer: a single-center, non-randomized analysis of efficacy and effects on gastrointestinal symptoms and metabolic acidosis. BMC Nephrol. 12, 14:222.

Hattori, K., Maeda, T., Nishida, S., Imanishi, M., Sakaguchi, M., Amari, Y., Moriya, T., Hirose, Y., 2017. Correlation of lanthanum dosage with lanthanum deposition in the gastroduodenal mucosa of dialysis patients. Pathol. Int. 67, 447-452.

Helal, I., Elkateb, H., Hedri, H., Hajri, M., Hamida, F.B., 2016. Efficacy and safety of calcium acetate-magnesium carbonate in the treatment of hyperphosphatemia in dialysis patients. Saudi J. Kidney Dis. Transplant. 27, 1162-1167.

Hill, N.R., Fatoba, S.T., Oke, J.L., Hirst, J.A., O'Callaghan, C.A., Lasserson, D.S., Hobbs, F.D.R., 2016. Global prevalence of chronic kidney disease - a systematic review and meta-analysis. Plos One DOI:10.1371/journal.pone.0158765; 2016, p: 18.

Hoda, R.S., Sanyal, S., Abraham, J.L., Everett, J.M., Hundemer, G.L., Yee, E., Lauwers, G.Y., Tolkoff-Rubin, N., Misdraji, J., 2017. Lanthanum deposition from oral lanthanum carbonate in the upper gastrointestinal tract. Histopathology $70,1072-1078$.

Hu, X., Shang, J., Yuan, W., Zhang, S., Jiang, Y., Zhao, B., Duan, Y., Xiao, J., Zhao, Z., 2017. Effects of paricalcitol on cardiovascular outcomes and renal function in patients with chronic kidney disease: a metaanalysis. Herz. DOI: 10.1007/s00059-017-4605-y.

Hutchison, A.J., Barnett, M.E., Krause, R.J., Siami, G.A., Lanthanum Carbonate Study Group, 2009. Lanthanum carbonate treatment, for up to 6 years, is not associated with adverse effects on the liver in patients with chronic kidney disease Stage 5 receiving hemodialysis. Clin. Nephrol. 71, 286-295.

Hutchison, A.J., Wilkie, M., 2012. Use of magnesium as a drug in chronic kidney disease. Clin. Kidney J. 5(Suppl 1), i62i70.

Hutchison, AJ., Wilson, RJ., Garafola, S., Copley, JB., 2016. Lanthanum carbonate: safety data after 10 years. Nephrology (Carlton) 21, 987-994.

Iida, A., Kemmochi, Y., Kakimoto, K., Tanimoto, M., Mimura, T., Shinozaki, Y., Uemura, A., Matsuo, A., Matsushita, M., Miyamoto, K., 2013. Ferric citrate hydrate, a new phosphate binder, prevents the complications of secondary hyperparathyroidism and vascular calcification. Am. J. Nephrol. 37, 346-358.

Iimori, S., Mori, Y., Akita, W., Takada, S., Kuyama, T., Ohnishi, T., Shikuma, S., Ishigami, J., Tajima, M., Asai, T., Okado, T., Kuwahara, M., Sasaki, S., Tsukamoto, Y., 2012. Effects of sevelamer hydrochloride on mortality, lipid abnormality and arterial stiffness in hemodialyzed patients: a propensity-matched observational study. Clin. Exp. Nephrol. 16, 930-937.

Ikee, R., Toyoyama, T., Endo, T., Tsunoda, M., Hashimoto, N., 2016. Impact of sevelamer hydrochloride on serum 
magnesium concentrations in hemodialysis patients. Magnes. Res. 29, 184-190.

Inaba, M., Okuno, S., Nagayama, H., Yamada, S., Ishimura, E., Imanishi, Y., Shoji, S., 2015. Restoration of parathyroid function after change of phosphate binder from calcium carbonate to lanthanum carbonate in hemodialysis patients with suppressed serum parathyroid hormone. J. Ren. Nutr. 25, 242-246.

Isakova, T., Gutiérrez, O.M., Chang, Y., Shah, A., Tamez, H., Smith, K., Thadhani, R., Wolf, M., 2009. Phosphorus binders and survival on hemodialysis. J. Am. Soc. Nephrol. 20, 388-396.

Ito, H., Ogata, H., Yamamoto, M., Takahashi, K., Shishido, K., Takahashi, J., Taguchi, S., Kinugasa, E., 2009. Comparison of oral falecalcitriol and intravenous calcitriol in hemodialysis patients with secondary hyperparathyroidism: a randomized, crossover trial. Clin. Nephrol. 71, 660-668.

Ito, K., Takeshima, A., Shishido, K., Wakasa, M., Kumata, C., Matsuzaka, K., Nakajima, Y., Ogata, H., 2014. Treatment of hyperphosphatemia with bixalomer in Japanese patients on long-term hemodialysis with gastrointestinal symptoms. Ther. Apher. Dial. 18(Suppl), 19-23.

Jamal, S.A., Fitchett, D., Lok, C.E., Mendelssohn, D.C., Tsuyuki, R.T., 2009. The effects of calcium-based versus non-calcium-based phosphate binders on mortality among patients with chronic kidney disease: a metaanalysis. Nephrol. Dial. Transplant. 24, 3168-3174.

Jamal, S.A., Vandermeer, B., Raggi, P., Mendelssohn, D.C., Chatterley, T., Dorgan, M., Lok, C.E., Fitchett, D., Tsuyuki, R.T., 2013. Effect of calcium-based versus non-calcium-based phosphate binders on mortality in patients with chronic kidney disease: an updated systematic review and meta-analysis. Lancet 12, 1268-1277.

Janssen, M.J., van der Kuy, A., ter Wee, P.M., van Boven, W.P., 1996. Aluminum hydroxide, calcium carbonate and calcium acetate in chronic intermittent hemodialysis patients. Clin. Nephrol. 45, 111-119.

Jean, G., Lataillade, D., Genet, L., Legrand, E., Kuentz, F., Moreau-Gaudry, X., Fouque, D., ARNOS study investigators, 2011. Calcium carbonate, but not sevelamer, is associated with better outcomes in hemodialysis patients: results from the French ARNOS study. Hemodial. Int. 15, 485-492.

Kahlon, D.K., Dinand, V., Yadav, S.P., Sachdeva, A., 2016. Sevelamer is an effective drug in treating hyperphosphatemia due to tumor lysis syndrome in children: a developing world experience. Ind. J. Hematol. Blood Transfus. 32, 78-82.

Kakuta, T., Tanaka, R., Hyodo, T., Suzuki, H., Kanai, G., Nagaoka, M., Takahashi, H., Hirawa, N., Oogushi, Y., Miyata, T., Kobayashi, H., Fukagawa, M., Saito, A., 2011. Effect of sevelamer and calcium-based phosphate binders on coronary artery calcification and accumulation of circulating advanced glycation end products in hemodialysis patients. Am. J. Kidney Dis. 57, 422-431.

Katopodis, K.P., Andrikos, E.K., Gouva, C.D., Bairaktari, E.T., Nikolopoulos, P.M., Takouli, L.K., Tzallas, C.S., Elisaf, M.S., Pappas, M.V., Siamopoulos, K.C., 2006. Sevelamer hydrochloride versus aluminum hydroxide: effect on serum phosphorus and lipids in CAPD patients. Perit. Dial. Int. 26, 320-327.

Kawata, T., Nagano, N., Obi, M., Miyata, S., Koyama,
C., Kobayashi, N., Wakita, S., Wada, M., 2008. Cinacalcet suppresses calcification of the aorta and heart in uremic rats. Kidney Int. 74, 1270-1277.

Kays, M.B., Overholser, B.R., Mueller, B.A., Moe, S.M., Sowinski, K.M., 2003. Effects of sevelamer hydrochloride and calcium acetate on the oral bioavailability of ciprofloxacin. Am. J. Kidney Dis. 42, 1253-1259.

Khan, A., Bilezikian, J., Bone, H., Gurevich, A., Lakatos, P., Misiorowski, W., Rozhinskaya, L., Trotman, M.L., Tóth, M., 2015. Cinacalcet normalizes serum calcium in a double-blind randomized, placebo-controlled study in patients with primary hyperparathyroidism with contraindications to surgery. Eur. J. Endocrinol. 172, 527535 .

Kim, J., Olson, K., Butani, L., 2016. Sevelamer crystals in the mucosa of the gastrointestinal tract in a teenager with endstage renal disease. Pediatr. Nephrol. 31, 339-341.

Koiwa, F., Yokoyama, K., Fukagawa, M., Akizawa, T., 2017a. Long-term assessment of the safety and efficacy of PA21 (sucroferric oxyhydroxide) in Japanese hemodialysis patients with hyperphosphatemia: an open-label, multicenter, phase III study. J. Ren. Nutr. 27, 346-354.

Koiwa, F., Yokoyama, K., Fukagawa, M., Terao, A., Akizawa, T., 2017b. Efficacy and safety of sucroferric oxyhydroxide compared with sevelamer hydrochloride in Japanese haemodialysis patients with hyperphosphataemia: A randomized, open-label, multicentre, 12-week phase III study. Nephrology (Carlton) 22, 293-300.

Kokuho, T., Toya, Y., Kawaguchi, Y., Tamura, K., Iwatsubo, K., Dobashi, Y., Nakazawa, A., Takeda, H., Iwatsubo, M., Hirawa, N., Yasuda, G., Ohnishi, T., Umemura, S., 2007. Sevelamer hydrochloride improves hyperphosphatemia in hemodialysis patients with low bone turnover rate and low intact parathyroid hormone levels. Ther. Apher. Dial. 11, 442-448.

Kubotera, N., Prokopienko, A.J., Garba, A.O., Pai, A.B., 2013. Endotoxin binding by sevelamer: potential impact on nutritional status. Int. J. Nephrol. 2013, 954956.

Kuro-o, M., 2010. Overview of the FGF23-Klotho axis. Pediatr. Nephrol. 25, 583-590.

Lee, C.T., Wu, I.W., Chiang, S.S., Peng, Y.S., Shu, K.H., Wu, M.J., Wu, M.S., 2015. Effect of oral ferric citrate on serum phosphorus in hemodialysis patients: multicenter, randomized, double-blind, placebo-controlled study. J. Nephrol. 28, 105-113.

Lemos, M.M., Watanabe, R., Carvalho, A.B., Jancikic, A.D., Sanches, F.M., Christofalo, D.M., Draibe, S.A., Canziani, M.E., 2013. Effect of rosuvastatin and sevelamer on the progression of coronary artery calcification in chronic kidney disease: a pilot study. Clin. Nephrol. 80, 1-8.

Lewis, J.B., Sika, M., Koury, M.J., Chuang, P., Schulman, G., Smith, M.T., Whittier, F.C., Linfert, D.R., Galphin, C.M., Athreya, B.P., Nossuli, A.K., Chang, I.J., Blumenthal, S.S., Manley, J., Zeig, S., Kant, K.S., Olivero, J.J., Greene, T., Dwyer, J.P., Collaborative Study Group, 2015. Ferric citrate controls phosphorus and delivers iron in patients on dialysis. J. Am. Soc. Nephrol. 26, 493-503.

Lin, C.J., Pan, C.F., Chuang, C.K., Liu, H.L., Huang, S.F., Chen, H.H., Wu, C.J., 2017. Effects of sevelamer hydrochloride on uremic toxins serum indoxyl sulfate and p-cresyl sulfate in hemodialysis patients. J. Clin. Med. 
Res. 9, 765-770.

Lin, H.H., Liou, H.H., Wu, M.S., Huang, C.C., 2016. Factors associated with serum fetuin-A concentrations after longterm use of different phosphate binders in hemodialysis patients. BMC Nephrol. 17, 33.

Lin, H.H., Liou, H.H., Wu, M.S., Lin, C.Y., Huang, C.C., 2014. Long-term sevelamer treatment lowers serum fibroblast growth factor 23 accompanied with increasing serum Klotho levels in chronic haemodialysis patients. Nephrology (Carlton) 19, 672-678.

Lin, Y.F., Chen, Y.M, Hung, K.Y., Chu, T.S., Kan, W.C., Huang, C.Y., Lin, S.L., Kao, T.W., Huang, J.W., Chiang, W.C., Yen, C.J., Tsai, T.J., Wu, K.D., Wu, M.S., 2010. Benefits of sevelamer on markers of bone turnover in Taiwanese hemodialysis patients. J. Formos. Med. Assoc. 109, 663-672.

Lin, Y.F., Chien, C.T., Kan, W.C., Chen, Y.M., Chu, T.S., Hung, K.Y., Tsai, T.J., Wu, K.D., Wu, M.S., 2011. Pleiotropic effects of sevelamer beyond phosphate binding in end-stage renal disease patients: a randomized, openlabel, parallel-group study. Clin. Drug. Investig. 31, 257267.

Maahs, D.M., Snell-Bergeon, J.K., Kinney, G.L., Wadwa, R.P., Garg, S., Ogden, L.G., Rewers, M., 2007. ACE-I/ARB treatment in type 1 diabetes patients with albuminuria is associated with lower odds of progression of coronary artery calcification. J. Diabetes Complications 21, 273-279.

Malluche, H.H., Monier-Faugere, M.C., Wang, G., Frazã, O.J.M., Charytan, C., Coburn, J.W., Coyne, D.W., Kaplan, M.R., Baker, N., McCary, L.C., Turner, S.A., Goodman, W.G., 2008b. An assessment of cinacalcet $\mathrm{HCl}$ effects on bone histology in dialysis patients with secondary hyperparathyroidism. Clin. Nephrol. 69, 269-278.

Malluche, H.H., Siami, G.A., Swanepoel, C., Wang, G.H., Mawad, H., Confer, S., Smith, M., Pratt, R.D., Monier-Faugere, M.C., 2008a. SPD405-307 Lanthanum Carbonate Study Group. Improvements in renal osteodystrophy in patients treated with lanthanum carbonate for two years. Clin. Nephrol. 70, 284-295.

Manabe, R., Fukami, K., Ando, R., Sakai, K., Kusumoto, T., Hazama, T., Adachi, T., Kaida, Y., Nakayama, Y., Ueda, S., Kohno, K., Wada, Y., Yamagishi, S., Okuda, S., 2013. Effects of switching from calcium carbonate to lanthanum carbonate on bone mineral metabolism in hemodialysis patients. Ther. Apher. Dial. 17(Suppl), 35-40.

Mason, M.A., Shepler, B.M., 2010. Evaluation of morbidity and mortality data related to cardiovascular calcification from calcium-containing phosphate binder use in patients undergoing hemodialysis. Pharmacotherapy 30, 741-748.

Matias, P.J., Jorge, C., Azevedo, A., Laranjinha, I., Navarro, D., Mendes, M., Amaral, T., Ferreira, C., Aires, I., Gil, C., Stuard, S., Ferreira, A., 2016. Calcium acetate/magnesium carbonate and cardiovascular risk factors in chronic hemodialysis patients. Nephron 132, 317326.

McIntyre, C.W., Pai, P., Warwick, G., Wilkie, M., Toft, A.J., Hutchison, A.J., 2009. Iron-magnesium hydroxycarbonate (Fermagate): a novel non-calcium-containing phosphate binder for the treatment of hyperphosphatemia in chronic hemodialysis patients. Clin. J. Am. Soc. Nephrol. 4, 401409.

Milovanova, L.Iu., Dobrosmyslov, I.A., Milovanov, Iu.S., 2014. Experience with active vitamin D metabolites in phosphorus-calcium metabolic disorders in patients with predialysis chronic kidney disease. Ter. Arkh. 86, 52-56. Mizobuchi, M., Ogata, H., 2014. Clinical uses of 22oxacalcitriol. Curr. Vasc. Pharmacol. 12, 324-328.

Moe, S., Drueke, T., Cunningham, J., Goodman, W., Martin, K., Olgaard, K., Ott, S., Sprague, S., Lameire, N., Eknoyan, K., 2006. Definition, evaluation, and classification of renal osteodystrophy: A position statement from kidney disease: improving global outcomes (KDIGO). Kidney Int. 69, 1945-1953.

Moe, S.M., Abdalla, S., Chertow, G.M., Parfrey, P.S., Block, G.A., Correa-Rotter, R., Floege, J., Herzog, C.A., London, G.M., Mahaffey, K.W., Wheeler, D.C., Dehmel, B., Goodman, W.G., Drüeke, T.B., Evaluation of cinacalcet $\mathrm{HCl}$ therapy to lower cardiovascular events (EVOLVE) trial investigators., 2015. Effects of cinacalcet on fracture events in patients receiving hemodialysis: The EVOLVE Trial. J. Am. Soc. Nephrol. 26, 1466-1475.

Moe, S.M., Saifullah, A., LaClair, R.E., Usman, S.A., Yu, Z., 2010. A randomized trial of cholecalciferol versus doxercalciferol for lowering parathyroid hormone in chronic kidney disease. Clin. J. Am. Soc. Nephrol. 5, 299306.

Mudge, D.W., Johnson, D.W., Hawley, C.M., Campbell, S.B., Isbel, N.M., van Eps, C.L., Petrie, J.J.B., 2011. Do aluminium-based phosphate binder continue to have a role in contemporary nephrology practice? BMC Nephrology 12, 20, 8 pages.

Murakami, N., Yoshioka, M., Iwamuro, M., Nasu, J., Nose, S., Shiode, J., Okada, H., Yamamoto, K., 2017. Clinical characteristics of seven patients with lanthanum phosphate deposition in the stomach. Intern. Med. 56, 2089-2095.

Nakanishi, T., Hasuike, Y., Nanami, M., Yahiro, M., Kuragano, T., 2016. Novel iron-containing phosphate binders and anemia treatment in CKD: oral iron intake revisited. Nephrol. Dial. Transplant. 31, 1588-1594.

Nakayama, K., Nakao, K., Takatori, Y., Inoue, J., Kojo, S., Akagi, S., Fukushima, M., Wada, J., Makino, H., 2013. Long-term effect of cinacalcet hydrochloride on abdominal aortic calcification in patients on hemodialysis with secondary hyperparathyroidism. Int. J. Nephrol. Renovasc. Dis. 18, 25-33.

National Kidney Foundation, 2002. K/DOQI Clinical Practice Guidelines for Chronic Kidney Disease: Evaluation, Classification and Stratification. Am. J. Kidney Dis. 39 (suppl 1), S1-S266.

Navaneethan, S.D., Palmer, S.C., Vecchio, M., Craig, J.C., Elder, G.J., Strippoli, G.F., 2011. Phosphate binders for preventing and treating bone disease in chronic kidney disease patients. Cochrane Database Syst. Rev. 16(2), CD006023.

Navarro-González, J.F., Mora-Fernández, C., Muros de Fuentes, M., Donate-Correa, J., Cazaña-Pérez, V., GarcíaPérez J., 2011. Effect of phosphate binders on serum inflammatory profile, soluble CD14, and endotoxin levels in hemodialysis patients. Clin. J. Am. Soc. Nephrol. 6, 2272-2279.

Neradova, A., Schumacher, S.P., Hubeek, I., Lux, P., Schurgers, L.J., Vervloet, M.G., 2017. Phosphate binders affect vitamin $\mathrm{K}$ concentration by undesired binding, an in vitro study. BMC Nephrol. 18, 149.

Neven, E., De Schutter, T.M., Dams, G., Gundlach, K., Steppan, S., Büchel, J., Passlick-Deetjen, J., D'Haese, 
P.C., Behets, G.J., 2014. A magnesium based phosphate binder reduces vascular calcification without affecting bone in chronic renal failure rats. PLoS One 9, e107067.

Newton, M., Toft, A., Roberts, N.B., Minkeus, M., 2007. Study of the phosphate binding of Alpharen an iron magenesium hyroxycarbonate in a dynamic model of the gastrointestinal tract. EDTA Abstract SA P049.

Oh, M.S., Uribarri, J., 2014. What can we learn from the saga of chitosan gums in hyperphosphatemia therapy? Clin. J. Am. Soc. Nephrol. 9, 967-970.

Ohtake, T., Kobayashi, S., Oka, M., Furuya, R., Iwagami, M., Tsutsumi, D., Mochida, Y., Maesato, K., Ishioka, K., Moriya, H., Hidaka, S., Lanthanum carbonate delays progression of coronary artery calcification compared with calcium-based phosphate binders in patients on hemodialysis: a pilot study. J. Cardiovasc. Pharmacol. Ther. 18, 439-446.

Oka, Y., Miyazaki, M., Matsuda, H., Takatsu, S., Katsube, R., Mori, T., Takehara, K., Umeda, Y., Uno, F., 2014 Sevelamer hydrochloride dose-dependent increase in prevalence of severe acidosis in hemodialysis patients: analysis of nationwide statistical survey in Japan. Ther. Apher. Dial. 18, 37-43

Oliveira, R.B., Cancela, A.L., Graciolli, F.G., Dos Reis, L.M., Draibe, S.A., Cuppari, L., Carvalho, A.B., Jorgetti, V., Canziani, M.E., Moysés, R.M., 2010. Early control of PTH and FGF23 in normophosphatemic CKD patients: a new target in CKD-MBD therapy? Clin. J. Am. Soc. Nephrol. 5, 286-291.

Ouellet, G., Cardinal, H., Mailhot, M., Ste-Marie, L.G., Roy, L., 2010. Does concomitant administration of sevelamer and calcium carbonate modify the control of phosphatemia? Ther. Apher. Dial. 14, 172-177.

Padhi, D., Harris, R., Sullivan, J.T., 2014. Effects of calcium carbonate, sevelamer hydrochloride or pantoprazole on the pharmacokinetics of cinacalcet. Clin. Drug Investig. 34, 537-544.

Pai, A.B., Shepler, B.M., 2009. Comparison of sevelamer hydrochloride and sevelamer carbonate: risk of metabolic acidosis and clinical implications. Pharmacotherapy 29, 554-561.

Pasch, A., Block, G.A., Bachtler, M., Smith, E.R., JahenDechent, W., Arapatzis, S., Shertow, G.M., Parfrey, P., Ma, X., Floege, J., 2017. Blood calcification propensity, cardiovascular evenst, and survival in patients receiving hemodialysis in the EVOLVE trial. Clin. J. Am. Soc. Nephrol. 12, 315-322.

Patel, L., Bernard, L.M., Elder, G.J., 2016. Sevelamer versus calcium-based binders for treatment of hyperphosphatemia in CKD: a meta-analysis of randomized controlled trials. Clin. J. Am. Soc. Nephrol. 11, 232-244.

Phan, O., Maillard, M., Malluche, H.H., Stehle, J.C., Funk, F., Burnier, M., 2015.. Sucroferric oxyhydroxide compared to lanthanum carbonate and sevelamer carbonate on phosphate homeostasis and vascular calcifications in a rat model of chronic kidney failure. Biomed. Res. Int. 2015, 515606.

Pieper, A.K., Buhle, F., Bauer, S., Mai, I., Budde, K., Haffner, D., 2004. Neumayer HH, Querfeld U. The effect of sevelamer on the pharmacokinetics of cyclosporin A and mycophenolate mofetil after renal transplantation. Nephrol. Dial. Transplant. 19, 2630-2633.

Pierce, D., Hossack, S., Poole, L., Robinson, A., Van Heusen,
H., Martin, P., Smyth, M., 2011. The effect of sevelamer carbonate and lanthanum carbonate on the pharmacokinetics of oral calcitriol. Nephrol. Dial. Transplant. 26, 1615-1621.

Pruchnicki, M.C., Coyle, J.D., Hoshaw-Woodard, S., Bay, W.H., 2002. Effect of phosphate binders on supplemental iron absorption in healthy subjects. J. Clin. Pharmacol. 42, 1171-1176.

Qunibi, W., Moustafa, M., Muenz, L.R., He, D.Y., Kessler, P.D., Diaz-Buxo, J.A., Budoff, M., CARE-2 Investigators, 2008. A 1-year randomized trial of calcium acetate versus sevelamer on progression of coronary artery calcification in hemodialysis patients with comparable lipid control: the Calcium Acetate Renagel Evaluation-2 (CARE-2) study. Am. J. Kidney Dis. 51, 952-965.

Raggi, P., Chertow, G.M., Torres, P.U., Csiky, B., Naso, A., Nossuli, K., Moustafa, M., Goodman, W.G., Lopez, N., Downey, G., Dehmel, B., Floege, J., 2011. The ADVANCE study: a randomized study to evaluate the effects of cinacalcet plus low-dose vitamin $\mathrm{D}$ on vascular calcification in patients on hemodialysis. Nephrol. Dial. Transplant. 26, 1327-1339.

Raggi, P., James, G., Burke, S.K., Bommer, J., Chasan-Taber, S., Holzer, H., Braun, J., Chertow, G.M., 2005. Decrease in thoracic vertebral bone attenuation with calcium-based phosphate binders in hemodialysis. J. Bone Miner. Res. 20, 764-772.

Rauscher, S., Lafrance, J.P., Pichette, V., Bell, R.Z., Desforges, K., Lepage, L., Ouellet, G., Ouimet, D., Leblanc, M., Lamarche, C., Bezzaoucha, S., Vallee, M., 2017. Conversion of oral alfacalcidol to oral calcitriol in the treatment of secondary hyperparathyroidism in chronic hemodialysis patients. Int. Urol. Nephrol. 49, 325-328.

Rees, L., Shroff, R., 2015. The demise of calcium-based phosphate binders - is this appropriate for children? Pediatr. Nephrol. 30, 2061-2071.

Rosa-Diez, G., Negri, A.L., Crucelegui, M.S., Philippi, R., Perez-Teysseyre, H., Sarabia-Reyes, C., Loor-Navarrete, H., Heguilen, R., 2016. Sevelamer carbonate reduces the risk of hypomagnesemia in hemodialysis-requiring endstage renal disease patients. Clin. Kidney J. 9, 481-485.

Russo, D., Miranda, I., Ruocco, C., Battaglia, Y., Buonanno, E., Manzi, S., Russo, L., Scafarto, A., Andreucci, V.E., 2007. The progression of coronary artery calcification in predialysis patients on calcium carbonate or sevelamer. Kidney Int. 72, 1255-1261.

Saif, I., Halim, A., Altaf, A., Saif, M., Khalid, M., Ahmad, D., Imran, H., 2007. Comparison of calcium acetate with calcium carbonate as phosphate binder in patients on maintenance haemodialysis. J. Ayub. Med. Coll. Abbottabad. 19, 26-28.

Sanai, T., Tada, H., Ono, T., Fukumitsu, T., 2015. Phosphate binders and metabolic acidosis in patients undergoing maintenance hemodialysis-sevelamer hydrochloride, calcium carbonate, and bixalomer. Hemodial. Int. 19, 5459

Sandler, N.G., Zhang, X., Bosch, R.J., Funderburg, N.T., Choi, A.I., Robinson, J.K., Fine, D.M., Coombs, R.W., Jacobson, J.M., Landay, A.L., Douek, D.C., Tressler, R., Read, S.W., Wilson, C.C., Deeks, S.G., Lederman, M.M., Gandhi, R.T., AIDS Clinical Trials Group A5296 Team, 2014. Sevelamer does not decrease lipopolysaccharide or soluble CD14 levels but decreases soluble tissue factor, low-density 
lipoprotein (LDL) cholesterol, and oxidized LDL cholesterol levels in individuals with untreated HIV infection. J. Infect. Dis. 210, 1549-1554.

Schmid, H., Lederer, S.R., 2015. Novel iron-containing phosphate binders for treatment of hyperphosphatemia. Expert. Opin. Pharmacother. 16, 2179-2191.

Sekercioglu, N., Angeliki Veroniki, A., Thabane, L., Busse, J.W., Akhtar-Danesh, N., Iorio, A., Cruz Lopes, L., Guyatt, G.H., 2017. Effects of different phosphate lowering strategies in patients with CKD on laboratory outcomes: A systematic review and NMA. PLoS One 12, e0171028.

Sekercioglu, N., Thabane, L., Díaz Martínez, J.P., Nesrallah, G., Longo, C.J., Busse, J.W., Akhtar-Danesh, N., Agarwal, A., Al-Khalifah, R., Iorio, A., Guyatt, G.H., 2016. Comparative effectiveness of phosphate binders in patients with chronic kidney disease: a systematic review and network meta-analysis. PLoS One 8, e0156891.

Shaman, A.M., Kowalski, S.R., 2016. Hyperphosphatemia management in patients with chronic kidney disease. Saudi Pharm. J. 24, 494-505.

Shigematsu, T., Nakashima, Y., Ohya, M., Tatsuta, K., Koreeda, D., Yoshimoto, W., Yamanaka, S., Sakaguchi, T., Hanba, Y., Mima, T., Negi, S., 2012. The management of hyperphosphatemia by lanthanum carbonate in chronic kidney disease patients. Int. J. Nephrol. Renovasc. Dis. 5, 81-89.

Shigematsu, T., Tokumoto, A., Nakaoka, A., Arisaka, H., 2011. Effect of lanthanum carbonate treatment on bone in Japanese dialysis patients with hyperphosphatemia. Ther. Apher. Dial. 15, 176-184.

Shitomi, Y., Nishida, H., Kusaba, T., Daa, T., Yano, S., Arakane, M., Kondo, Y., Nagai, T., Abe, T., Gamachi, A., Murakami, K., Etoh, T., Shiraishi, N., Inomata, M., Yokoyama, S., 2017. Gastric lanthanosis (lanthanum deposition) in dialysis patients treated with lanthanum carbonate. Pathol. Int. 67, 389-397.

Shroff, R., Wan, M., Nagler, E.V., Bakkaloglu, S., Cozzolino, M., Bacchetta, J., Edefonti, A., Stefanidis, CJ., Vande Walle, J., Ariceta, G., Klaus, G., Haffner, D., Schmitt, CP. European Society for Paediatric Nephrology Chronic Kidney Disease Mineral and Bone Disorders and Dialysis Working Groups. Clinical practice recommendations for treatment with active vitamin D analogues in children with chronic kidney disease Stages 2-5 and on dialysis. Nephrol. Dial. Transplant. 32, 1114-1127.

Slatopolsky, E., Liapis, H., Finch, J., 2005. Progressive accumulation of lanthanum in the liver of normal and uremic rats. Kidney Int. 68, 2809-2813.

Soriano, S., Ojeda, R., Rodríguez, M., Almadén, Y., Rodríguez, M., Martín-Malo, A., Aljama, P., 2013. The effect of phosphate binders, calcium and lanthanum carbonate on FGF23 levels in chronic kidney disease patients. Clin. Nephrol. 80, 17-22.

Spatz, C., Roe, K., Lehman, E., Verma, N., 2013. Effect of a non-calcium-based phosphate binder on fibroblast growth factor 23 in chronic kidney disease. Nephron. Clin. Pract. 123, 61-66.

Spiegel, D.M., 2011. Magnesium in chronic kidney disease: unanswered questions. Blood Purif. 31, 172-176.

Spiegel, D.M., Farmer, B., 2009. Long-term effects of magnesium carbonate on coronary artery calcification and bone mineral density in hemodialysis patients: a pilot study. Hemodial. Int. 13, 453-459.
Sprague, S.M., Wetmore, J.B., Gurevich, K., Da Roza, G., Buerkert, J., Reiner, M., Goodman, W., Cooper, K., 2015. Effect of cinacalcet and vitamin D Analogs on fibroblast growth factor-23 during the treatment of secondary hyperparathyroidism. Clin. J. Am. Soc. Nephrol. 10, 1021-1030.

St Peter, W.L., Liu, J., Weinhandl, E., Fan, Q., 2008. A comparison of sevelamer and calcium-based phosphate binders on mortality, hospitalization, and morbidity in hemodialysis: a secondary analysis of the Dialysis Clinical Outcomes Revisited (DCOR) randomized trial using claims data. Am. J. Kidney Dis. 51, 445-454.

Stinghen, A.E., Gonçalves, S.M., Bucharles, S., Branco, FS., Gruber, B., Hauser, A.B., Pecoits-Filho, R., 2010. Sevelamer decreases systemic inflammation in parallel to a reduction in endotoxemia. Blood Purif. 29, 352-356.

Stojceva-Taneva, O., Otovic, N.E., Taneva, B., 2016. Prevalence of diabetes mellitus in patients with chronic kidney disease. OAMJMS 4, 79-82.

Takagi, K., Masuda, K., Yamazaki, M., Kiyohara, C., Itoh, S., Wasaki, M., Inoue, H., 2010. Metal ion and vitamin adsorption profiles of phosphate binder ion-exchange resins. Clin. Nephrol. 73, 30-35.

Takei, T., Otsubo, S., Uchida, K., Matsugami, K., Mimuro, T., Kabaya, T., Akiba, T., Nitta, K., 2008. Effects of sevelamer on the progression of vascular calcification in patients on chronic haemodialysis. Nephron Clin. Pract. 108, c278-83.

Taketani, Y., Masuda, M., Yamanaka-Okumura, H., Tatsumi, S., Segawa, H., Miyamoto, K., Takeda, E., Yamamoto, H., 2015. Niacin and chronic kidney disease. J. Nutr. Sci. Vitaminol. (Tokyo) 61(Suppl), S173-S175.

Takeuchi, K., Matsuda, E., Sekino, M., Hasegawa, Y., Kamo, Y., Kikuchi, N., Sekino, H., 2013. Three-year follow-up of lanthanum carbonate therapy in hemodialysis patients. Ther. Apher. Dial. 17(Suppl), 15-21.

Tanaka, M., Miyamura, S., Imafuku, T., Tominaga, Y., Maeda, H., Anraku, M., Yamasaki, K., Kadowaki, D., Ishima, Y., Watanabe, H., Okuda, T., Itoh, K., Matsushita, K., Fukagawa, M., Otagiri, M., Maruyama, T., 2016. Effect of a ferric citrate formulation, a phosphate binder, on oxidative stress in chronic kidney diseases-mineral and bone disorder patients receiving hemodialysis: a pilot study. Biol. Pharm. Bull. 39, 1000-1006.

Tanemoto, M., Ishimoto, Y., Saito, H., 2017. Oral lowdose ferric citrate is a useful iron source for hyperphosphatemic hemodialysis patients: a case series. Blood Purif. 43, 97-100.

Tonooka, A., Uda, S., Tanaka, H., Yao, A., Uekusa, T., 2015. Possibility of lanthanum absorption in the stomach. Clin. Kidney J. 8, 572-575.

Toussaint, N.D., Lau, KK., Polkinghorne, K.R., Kerr, P.G., 2011. Attenuation of aortic calcification with lanthanum carbonate versus calcium-based phosphate binders in haemodialysis: a pilot randomized controlled trial. Nephrology (Carlton) 16, 290-298.

Tsuchida, K., Nagai, K., Yokota, N., Minakuchi, J., Kawashima, S., 2016. Impact of lanthanum carbonate on prognosis of chronic hemodialysis patients: a retrospective cohort study (Kawashima Study). Ther. Apher. Dial. 20, 142-148.

Tzanakis, I.P., Stamataki, E.E., Papadaki, A.N., Giannakis, N., Damianakis, N.E., Oreopoulos, D.G., 2014. Magnesium 
retards the progress of the arterial calcifications in hemodialysis patients: a pilot study. Int. Urol. Nephrol. 46, 2199-2205.

Tzanno-Martins, C., Biavo, BM., Ferreira-Filho, O., RibeiroJunior, E., João-Luiz, M.V., Degaspari, S., Scavone, C., Kawamoto, E., 2014. Clinical efficacy, safety and antiinflammatory activity of two sevelamertablet forms in patients on low-flux hemodialysis. Int. J. Immunopathol. Pharmacol. 27, 25-35.

Ureña-Torres, P.A., Floege, J., Hawley, C.M., Pedagogos, E., Goodman, W.G., Pétavy, F., Reiner, M., Raggi P., 2013. Protocol adherence and the progression of cardiovascular calcification in the ADVANCE study. Nephrol. Dial. Transplant. 28, 146-152.

van Buren, P.N., Lewis, J.B., Dwyer, J.P., Greene, T., Middleton, J., Sika, M., Umanath, K., Abraham, J.D., Arfeen, S.S., Bowline, I.G., Chernin, G., Fadem, S.Z., Goral, S., Koury, M., Sinsakul, M.V., Weiner, D.E., Collaborative Study Group, 2015. The phosphate binder ferric citrate and mineral metabolism and inflammatory markers in maintenance dialysis patients: results from prespecified analyses of a randomized clinical trial. Am. J. Kidney Dis. 66, 479-488.

Vlassara, H., Uribarri, J., Cai, W., Goodman, S., Pyzik, R., Post, J., Grosjean, F., Woodward, M., Striker, G.E., 2012. Effects of sevelamer on HbA1c, inflammation, and advanced glycation end products in diabetic kidney disease. Clin. J. Am. Soc. Nephrol. 7, 934-942.

Wada, K., Wada, Y., Uchida, H.A., Tsuruoka, S., 2015. Effects of lanthanum carbonate versus calcium carbonate on vascular stiffness and bone mineral metabolism in hemodialysis patients with type 2 diabetes mellitus: a randomized controlled trial. Int. J. Nephrol. Renovasc. Dis. 26, 111-118.

Wang, C., Liu, X., Zhou, Y., Li, S., Chen, Y., Wang, Y., Lou, T., 2015b. New conclusions regarding comparison of sevelamer and calcium-based phosphate binders in coronary-artery calcification for dialysis patients: a metaanalysis of randomized controlled trials. PLoS One 31, e0133938.

Wang, Y., Xie, G., Huang, Y., Zhang, H., Yang, B., Mao, Z., 2015a. Calcium acetate or calcium carbonate for hyperphosphatemia of hemodialysis patients: a metaanalysis. PLoS One 23, e0121376.

Wesseling-Perry, K., Salusky, I.B., 2013. Phosphate binders, vitamin $\mathrm{D}$ and calcimimetics in the management of chronic kidney disease-mineral bone disorders (CKD-MBD) in children. Pediatr. Nephrol. 28, 617-625.

Wilson, R., Zhang, P., Smyth, M., Pratt, R., 2009. Assessment of survival in a 2-year comparative study of lanthanum carbonate versus standard therapy. Curr. Med. Res. Opin. 25, 3021-3028.

Wu, M., Tang, R.N., Liu, H., Pan, M.M., Liu, B.C., 2016. Cinacalcet ameliorates aortic calcification in uremis rats via suppression of endothelial-to-mesenchymal transition. Acta Pharmacol. Sin. 37, 1423-1431.
Yaguchi, A., Tatemichi, S., Takeda, H., Kobayashi, M., 2017. PA21, a novel phosphate binder, improves renal osteodystrophy in rats with chronic renal failure. PLoS One 13, e0180430.

Yaguchi, A., Yonekubo, S., Maruyama, I., Tatemichi, S., Maruyama, K., Kobayashi, M., 2016. Comparison of Phosphate Binding Capacities of PA21, A Novel Phosphate Binder, with those of other Phosphate Binders in vitro and in vivo. Drug Res. (Stuttg). 66, 262-269.

Yamaguschi, T., Ohyama, S., Furukawa, H., Sato, N., Ohnishi, I., Kasashia, S., Kawashima, A., Kayahara, M., 2016. Sigmoid colon diverticula perforation associated with sevelamer hydrochloride administration: A case report. Ann. Med. Surg. (Lond), 2, 57-60.

Yang, J.Y., Lee, T.C., Montez-Rath, M.E., Desai, M., Winkelmayer, W.C., 2013. Trends in the incidence of intestinal perforation in US dialysis patients (1992-2005). J. Nephrol. 26, 281-288.

Yang, Y., Mohammad, A., Berendt, R.T., Carlin, A., Khan, M.A., Faustinom P.J., 2016. Evaluation of the in vitro efficacy of sevelamer hydrochloride and sevelamer carbonate. J. Pharm. Sci. 105, 864-875.

Yilmaz, M.I., Sonmez, A., Saglam, M., Yaman, H., Kilic, S., Eyileten, T., Caglar, K., Oguz, Y., Vural, A., Yenicesu, M., Mallamaci, F., Zoccali, C., 2012. Comparison of calcium acetate and sevelamer on vascular function and fibroblast growth factor 23 in CKD patients: a randomized clinical trial. Am. J. Kidney Dis. 59, 177-185.

Yokoyama, K., Akiba, T., Fukagawa, M., Nakayama, M., Hirakata, H., 2014a. JTT-751 for treatment of patients with hyperphosphatemia on peritoneal dialysis. Nephron. Clin. Pract. 128, 135-140.

Yokoyama, K., Akiba, T., Fukagawa, M., Nakayama, M., Sawada, K., Kumagai, Y., Chertow, G.M., Hirakata, H., 2014b. Long-term safety and efficacy of a novel ironcontaining phosphate binder, JTT-751, in patients receiving hemodialysis. J. Ren. Nutr. 24, 261-267.

Yokoyama, K., Hirakata, H., Akiba, T., Fukagawa, M., Nakayama, M., Sawada, K., Kumagai, Y., Block, G.A., 2014c. Ferric citrate hydrate for the treatment of hyperphosphatemia in nondialysis-dependent CKD. Clin. J. Am. Soc. Nephrol. 9, 543-552.

Yokoyama, K., Hirakata, H., Akiba, T., Sawada, K., Kumagai, Y., 2012. Effect of oral JTT-751 (ferric citrate) on hyperphosphatemia in hemodialysis patients: results of a randomized, double-blind, placebo-controlled trial. Am. J. Nephrol. 36, 478-487.

Yuste, C., Merida, E., Hernandez, E., Garcia-Santiago, A., Rodriguez, Y., Munoz, T., Gomez, G.J., Sevillano, A., Praga, M., 2017. Gastrointestinal complications induced by sevelamer crystals. Clin. Kidney J. 10, 539-544.

Zhai, C.J., Yang, X.W., Sun, J., Wang, R., 2015. Efficacy and safety of lanthanum carbonate versus calcium-based phosphate binders in patients with chronic kidney disease: a systematic review and meta-analysis. Int. Urol. Nephrol. 47, 527-535. 


\title{
Резиме
}

\section{Управување со хиперфосфатемијата во хронично бубрежно заболување - ефекти врз васкуларната калцификација и коскеното здравје}

\author{
Димче Џингарски, Кристина Младеновска* \\ Фармацевтски факултет, Универзитет „Св. Кирил и Методиј”, \\ Бул. Мајка Тереза Бр. 47, 1000 Скопје, Република Македонија
}

Клучни зборови: хронично бубрежно заболување, хиперфосфатемија, врзувачи на фосфор, активни витамин Дстероли, пореметување на коските, кардиоваскуларна калцификација

Хиперфосфатемијата (ХФ) кај пациенти со хронично бубрежно заболување (ХБЗ) предизвикува низа компликации, како ренална остеодистрофија, кардиоваскуларна калцификација и хемодинамични абнормалности, сите со сериозно влијание врз стапката на преживување и квалитетот на живот. Дополнително, ХФ е клучен патоген фактор во развојот на секундарен хиперпаратироидизам (СХПТ) кај пациенти со ХБЗ. Имајќи ја предвид потребата од контрола на серумските нивоа на фосфорот, во овој труд се презентрани предизвиците и пречките во успешното управување со ХФ кај пациентите со ХБЗ, со детален преглед на главните класи на врзувачи на фосфор и на другите лекови кои влијаат врз нивоата на фосфор, како активните витамин Д-стероли и калцимиметиците (КМи). Дополнително, од особен интерес се нивните ефекти врз прогресијата на кардиоваскуларната калцификација и коскеното здравје. Во тој контекст, спроведено е истражување во PubMed-базата на податоци со кое се опфатени сите резимеа и трудови релевантни за темата ХБЗ, ХФ и минерален метаболизам, пореметувања на коските и васкуларна/валвуларна калцификација, публикувани во периодот јануари 2007 - август 2017. Пребарувањето е ограничено на публикации на англиски јазик, со користење на термини, кои ги опфаќаат името на лекот И ХФ или кардиоваскуларна калцификација или пореметување на коските. Направен е преглед на (компаративните) клинички студии и мета-анализи поврзани со различните класи/претставници на фосфатните врзувачи и другите лекови и споредувани се истражувачките резултати поврзани со нивната ефикасност и безбедност. 